\title{
The 1988 and 1990 Upland Earthquakes: Left-Lateral Faulting Adjacent to the Central Transverse Ranges
}

\author{
EGILL HAUKSSON \\ Seismological Laboratory, Division of Geological and Planetary Sciences, \\ California Institute of Technology, Pasadena
}

LUCILE M. JONES

U.S. Geological Survey, Pasadena, California

\begin{abstract}
Two earthquakes $\left(M_{L}=4.6\right.$ and $\left.M_{L}=5.2\right)$ occurred at almost the same location in Upland, southern California, in June 1988 and February 1990 and had similar strike-slip focal mechanisms with left-lateral motion on a northeast striking plane. The focal mechanisms and aftershock locations showed that the causative fault was the San Jose fault, an 18-km-long concealed fault that splays west-southwest from the frontal fault of the central Transverse Ranges. Left-lateral strike-slip faults adjacent to the frontal faults may play an important role in the deformation of the Transverse Ranges and the Los Angeles basin as suggested by these Upland earthquakes, the left-lateral strike-slip $1988\left(M_{L}=4.9\right)$ Pasadena earthquake on the Raymond fault, $30 \mathrm{~km}$ to the west of Upland, and scattered background seismicity along other active left-lateral faults. These faults may transfer slip away from part of the frontal fault toward the south. Alternatively, these faults could represent secondary faulting related to the termination of the northwest striking right-lateral strike-slip faults to the south of the range front. The 1988 and 1990 Upland earthquakes ruptured abutting or possibly overlapping segments of the San Jose fault. The edges of the overlapping aftershock zones, which are sharply defined, together with background seismicity, outline a 14-km-long aseismic segment of the San Jose fault. The 1988 mainshock originated at $9.5 \mathrm{~km}$ depth and caused aftershocks between 5 and $12 \mathrm{~km}$. In contrast, the 1990 mainshock focus occurred at the top of its aftershock zone, at $5 \mathrm{~km}$, and caused aftershocks down to $13 \mathrm{~km}$ depth. These deep aftershocks tapered off within 2 weeks. The rate of occurrence of aftershocks in magnitude-time space was the same for both sequences. The state of stress reflected in the focal mechanisms of the aftershocks is identical to that determined from background activity and did not change with time during the aftershock sequence. The constant stress state suggests that the 1988 and 1990 events did not completely release all the stored slip on that segment of the fault. The presence of $14 \mathrm{~km}$ of unbroken fault, the abrupt temporal termination of deep aftershocks, and the constant stress state all suggest that a future moderate-sized earthquake $\left(M_{L}=6.0-6.5\right)$ on the San Jose fault is possible with a rupture length of at least $14 \mathrm{~km}$ and possibly $18 \mathrm{~km}$.
\end{abstract}

\section{INTRODUCTION}

The $1988\left(M_{L}=4.6\right)$ and $1990\left(M_{L}=5.2\right)$ Upland earthquakes are separated by only $2 \mathrm{~km}$ horizontally and 4 $\mathrm{km}$ vertically. Their similar focal mechanisms and overlapping aftershock zones suggest that the two events occurred on abutting or possibly overlapping segments of one fault. Their location suggests that they occurred on the little known San Jose fault. The purpose of this paper is to analyze the spatial and temporal development of both sequences to determine if these two sequences indeed did overlap. Furthermore, these 1988 and 1990 earthquakes have only ruptured a 4-km length of the San Jose fault, which is at least $18 \mathrm{~km}$ long. It is therefore of considerable interest to know if there is any evidence for a continuation of this damaging earthquake sequence along this fault.

Copyright 1991 by the American Geophysical Union.

Paper number $91 \mathrm{JB} 00481$.

0148-0227/91/91JB-00481 $\$ 05.00$
The hypocenters of the 1988 and 1990 earthquakes occurred at almost the same location, less than $2 \mathrm{~km}$ to the south of the surface traces of the reverse faults that define the southern front of the central Transverse Ranges. These reverse faults extend from San Fernando Valley in the west to the San Andreas fault in the east [Crook et al., 1987; Morton and Matti, 1987]. A few late Quaternary leftlateral strike-slip faults, such as the Raymond fault and the San Jose fault, splay off the front southwestward. In addition to these faults, several northeast trending seismicity alignments that are not associated with known faults are also reported to the south of the range front (Figure 1). Both events showed left-lateral strike-slip motion on northeast striking planes and occurred on one of these left-lateral faults, the San Jose fault. In addition to the two Upland earthquakes the $M_{L}=4.9$ Pasadena earthquake was also caused by left-lateral strike-slip faulting nearby, on the Raymond fault in December 1988 [Jones et al., 1990].

How these northeast striking left-lateral faults and seismicity trends are related to the deformation along the thrust front is not clear. It is possible that these faults 


\section{East Los Angeles Basin \\ $M>1.5 \quad 1981$ - May 1990}

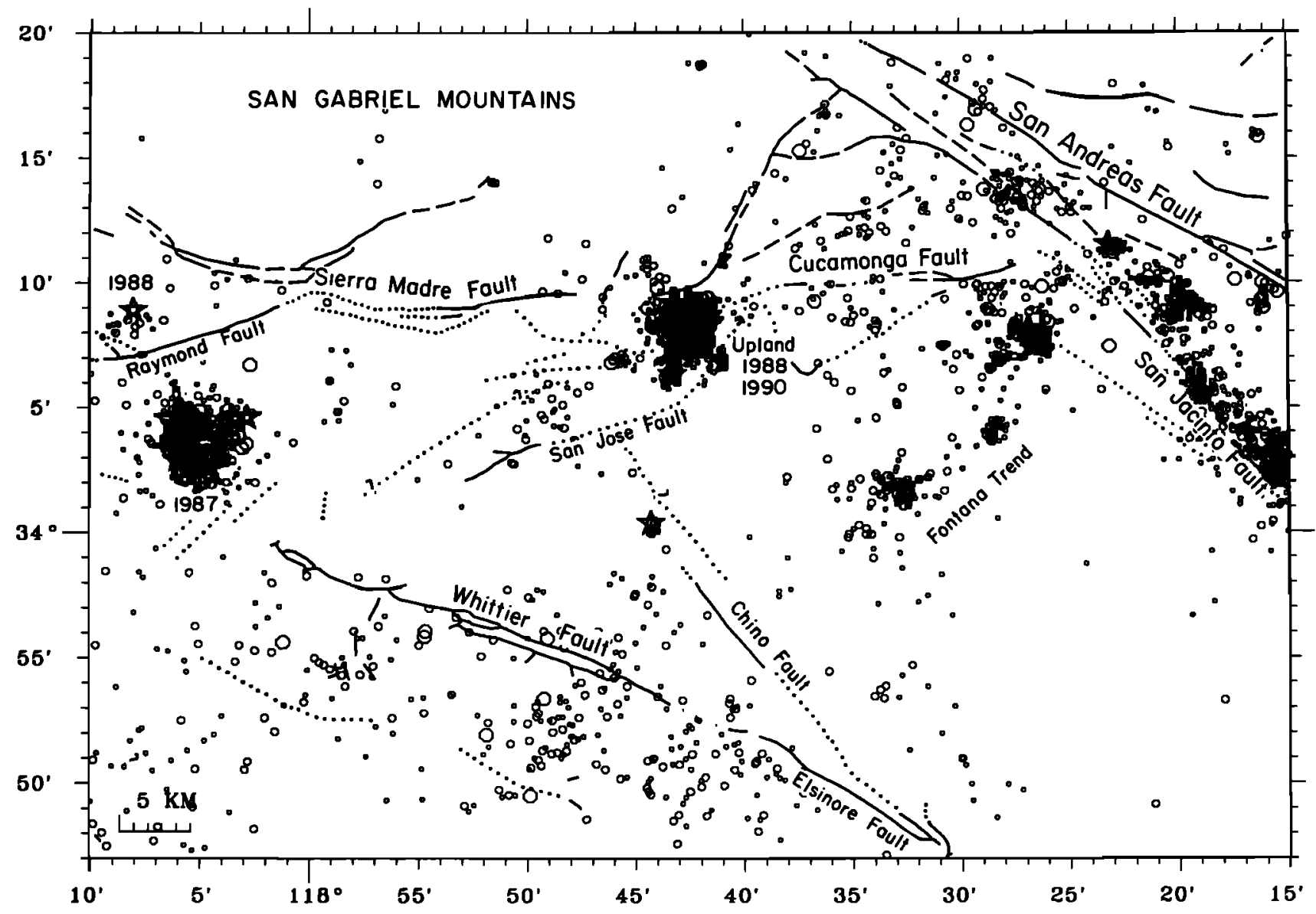

Fig. 1. A map of the eastern Los Angeles basin showing major faults (dotted if inferred) from Jennings [1975] and the locations of earthquakes $M_{L} \geq 1.5$ from 1981 to May 1990 recorded by the Southem California Seismic Network. Earthquakes of $M_{L} \geq 4.0$ are shown as stars. Dates of earthquakes $M_{L} \geq 4.9$ are given.

transfer slip away from part of the front to the south. Such a tectonic model requires that both concealed thrust faults and northwest striking strike-slip faults exist to the south and west to transfer motion back to the western part of the front to account for the total slip budget. Altematively, these left-lateral faults could be secondary, related merely to the termination of the northwest striking right-lateral strike-slip faults to the south. The Elsinore and the Chino faults terminate south of the range front near the San Jose fault (Figure 1) without any clear indication of how the fault motion is transferred from the right-lateral strike-slip regime to the reverse faults along the range front. Hauksson [1990] suggested decoupling of right-lateral strike-slip and dip-slip motion as a means of merging the two different regimes of faulting. Such a tectonic model is also consistent with the presence of these active left-lateral strike-slip faults.

The San Jose fault has been mapped solely on the basis of a water barrier [California Department of Water Resources (DWR), 1970]. Concealed water barriers similar to the San Jose fault have been mapped elsewhere in the Los Angeles basin [e.g., Yerkes et al., 1965]. Because many of these barriers are covered with undisturbed Holocene surfaces and in most cases are not associated with significant earthquake activity, their earthquake potential remains difficult to quantify [e.g., Ziony and Yerkes, 1985]. Analyzing the relationship between the 1988 and 1990 Upland earthquakes and the San Jose fault thus provides some of the first evidence of the earthquake potential of these concealed water barriers in the Los Angeles basin.

Two previous studies of background seismicity showed that both strike-slip and thrust faulting occur in the Upland area, in the northeastern corner of the Los Angeles region. The background seismicity of the Upland region was studied by Cramer and Harrington [1987] who deployed a portable network around the Cucamonga fault in spring of 1977. They recorded one left-lateral strike-slip focal mechanism near the northern end of the San Jose fault and a thrust mechanism near its southern end. Hauksson [1990] analyzed the background seismicity during 19771989 and reported several strike-slip and thrust fault focal mechanisms in the Upland area. Recent studies of the 1988 and 1990 Upland earthquakes have focused mostly on 
modeling on-scale waveforms. Mori and Hartzell [1990] used rupture directivity to show that the 1988 earthquake was caused by rupture on a fault with strike and dip consistent with the left-lateral plane of the focal mechanism, which is presented in this study. Using threecomponent data from the Pasadena station (PAS), Dreger and Helmberger [1990 and 1991] found that the waveforms of both the 1988 and 1990 events could be modeled with left-lateral focal mechanisms, which were consistent with both of the events occurring on the San Jose fault. The results of the waveform analysis are thus in overall agreement with the results of the analysis of phase data presented in this paper.

\section{Geological SeTting}

The geological setting of the epicentral area of the 1988 and 1990 Upland earthquakes is shown in Figure 2. Both earthquake sequences occurred between the inferred surficial traces of the San Jose and Indian Hill faults and the mapped surficial trace of the Cucamonga fault, which outcrops along the southern edge of the San Gabriel Mountains [Morton and Matti, 1987]. The alluvial fan south of the Cucamonga fault in the region of Figure 2 does not display surficial evidence of faulting and is on the average 500 feet thick [California DWR., 1970]. The San Jose and Indian Hill faults are identifiable because they cause significant discontinuities in the groundwater levels (Figure $2 b$ ). For instance, near Claremont the separation across the San Jose fault in the effective base of the freshwater aquifer is nearly 400 feet [California DWR, 1970]. The magnitude in vertical separation of this barrier across the San Jose fault is as great as that across the much more active San Jacinto fault located on the east side of the valley.

The San Jose fault can be traced as a water barrier from its abutment with the Cucamonga fault in the north to the San Jose Hills in the south for a distance of $18 \mathrm{~km}$. In the San Jose Hills it crops out for a distance of a few kilometers. Cramerand Harrington [1987] argued that the San Jose fault and also the Walnut Creek fault, located farther to the southwest, are major active tectonic features that accommodate the northerly movement of the tectonic block between the San Jacinto and Elsinore faults (Figure 1). The San Jacinto fault has a slip rate of 8-12 mm/yr [Ziony and Yerkes, 1985]. The convergence rate along the Cucamonga fault is of the order of $5 \mathrm{~mm} / \mathrm{yr}$ [Morton and Matti, 1987]. The slip rate along the San Jose fault is unknown but must be much less than the slip rate along the San Jacinto and Cucamonga faults, which have significant surficial Holocene offsets [e.g., Ziony and Jones, 1989].

The aquifer mapping and other geological data suggest that there is an apparent dip-slip separation on the San Jose fault. In Figure 3 the fault appears in two geological cross sections. The first cross section, $A-A^{\prime}$, from the 1:250,000-scale geologic map of the San Bernardino quadrangle, trends northeast from Pomona and shows a dipslip separation with the north side down [Bortugno and Spittler, 1986]. The second cross section, B-B', from the aquifer data, extends from the northwest to the southwest across both the Indian Hill and San Jose faults and shows the southeast side down [California DWR, 1970]. These seemingly contradictory vertical separations could result from mostly horizontal slip offsetting basement topography.

\section{DATA AND ANALYSIS}

The arrival time and $\boldsymbol{P}$ wave first-motion data from the Southern California Seismic Network operated by the U.S. Geological Survey and the California Institute of Technology (USGS/CIT) were used to obtain high-quality hypocenters and focal mechanisms. Arrival time data from the 1987 Whittier Narrows blast [Hauksson and Jones, 1989] and 157 events that occurred both in 1988 and in 1990 were simultaneously inverted for improved hypocenters, two velocity models, and a set of station delays using the VELEST code [Roecker and Ellsworth, 1978]. An initial model from Hadley and Kanamori [1977] was used as a starting regional model in the inversion, and a separate velocity model was assigned to stations located on sediments in the Los Angeles basin. The resultant models and delays were used as input to HYPOINVERSE [Klein, 1985] to obtain final locations for both sequences, which included more than 1100 events. The final locations on the average had a root-mean-square residual ( $\mathrm{rms}$ ) of $0.05 \mathrm{~s}$ as compared with the average $\mathrm{mms}$ of the catalog hypocenters of $0.20 \mathrm{~s}$.

Single-event, lower hemisphere focal mechanisms were determined for $124 M_{L} \geq 2.1$ earthquakes from 1990 and eight $M_{L} \geq 3.0$ earthquakes between 1986 and 1989 using the grid-searching algorithm and computer programs by Reasenberg and Oppenheimer [1985]. The focal mechanisms (Figure 4 and Table 1) were inverted for the orientation of the principal stress axes and a measure of their relative magnitude $(\phi)$, with a technique developed by Michael [1984]. The inversion minimizes the misfit angle (B) between the direction of the shear stress on the fault plane and the observed slip direction on that plane determined from the focal mechanism. The inversion technique assumes that the regional stress field is a constant tensor, all slip events are independent, and the magnitude of the tangential traction (ITI) applied to each fault plane is similar. The $\phi$ value is defined as

$$
\phi=\frac{\left(\sigma_{2}-\sigma_{3}\right)}{\left(\sigma_{1}-\sigma_{3}\right)}
$$

where $\sigma_{1}, \sigma_{2}$, and $\sigma_{3}$ are the maximum, intermediate, and minimum principal compressive stresses, respectively. One plane must be selected from each focal mechanism as the actual fault plane [Michael, 1987a]. The bootstrap technique used for calculating the $95 \%$ confidence limits accounts for incorrectly picked planes by assuming that $30 \%$ of the planes are picked incorrectly [Michael, 1987b].

\section{REsUlts}

\section{Background Seismicity}

The seismicity that occurred in the northeastem corner of the Los Angeles region, including the Upland area, from 1981 to 1989 is shown in Figure 5. These events have been relocated using the new velocity models and station delays. Most of the seismicity in this area is located to the south of the Sierra Madre-Cucamonga faults (see also 

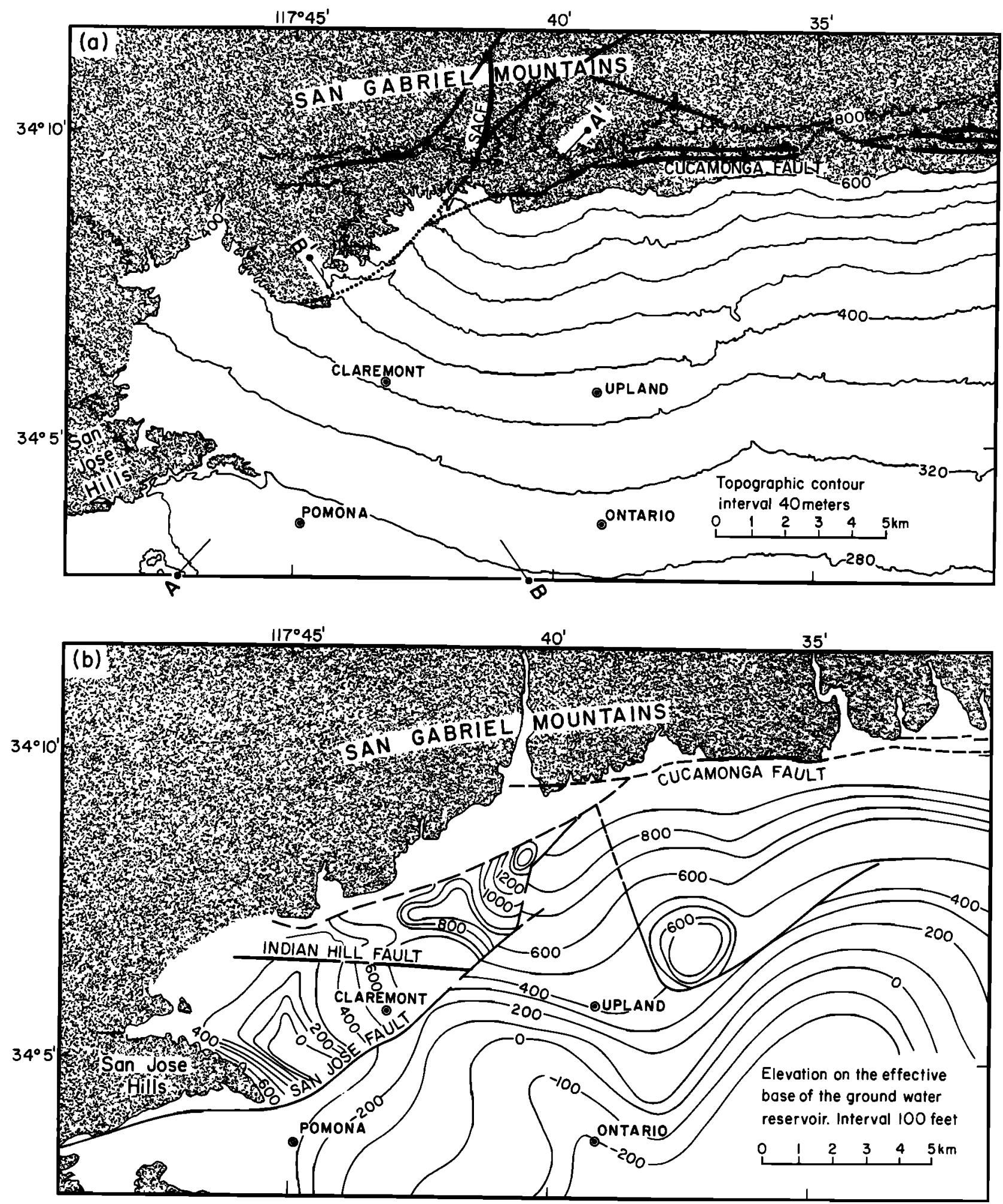

Fig. 2. Maps of the Upland area. Shaded areas are bedrock, and white areas are alluvial fill. (a) A topographic map showing 40-m contours of the elevation above sea level for alluvial deposits and active faults [U.S. Geological Survey, 1981]. Mapped faults are from Morton and Matti [1987]. Also shown are the end points $A-A^{\prime}$ and B-B' for the cross sections in Figure 3. (b) A map showing contours of the effective base of the groundwater reservoir and active faults as derived from the offsets in groundwater levels from California DWR [1970]. 

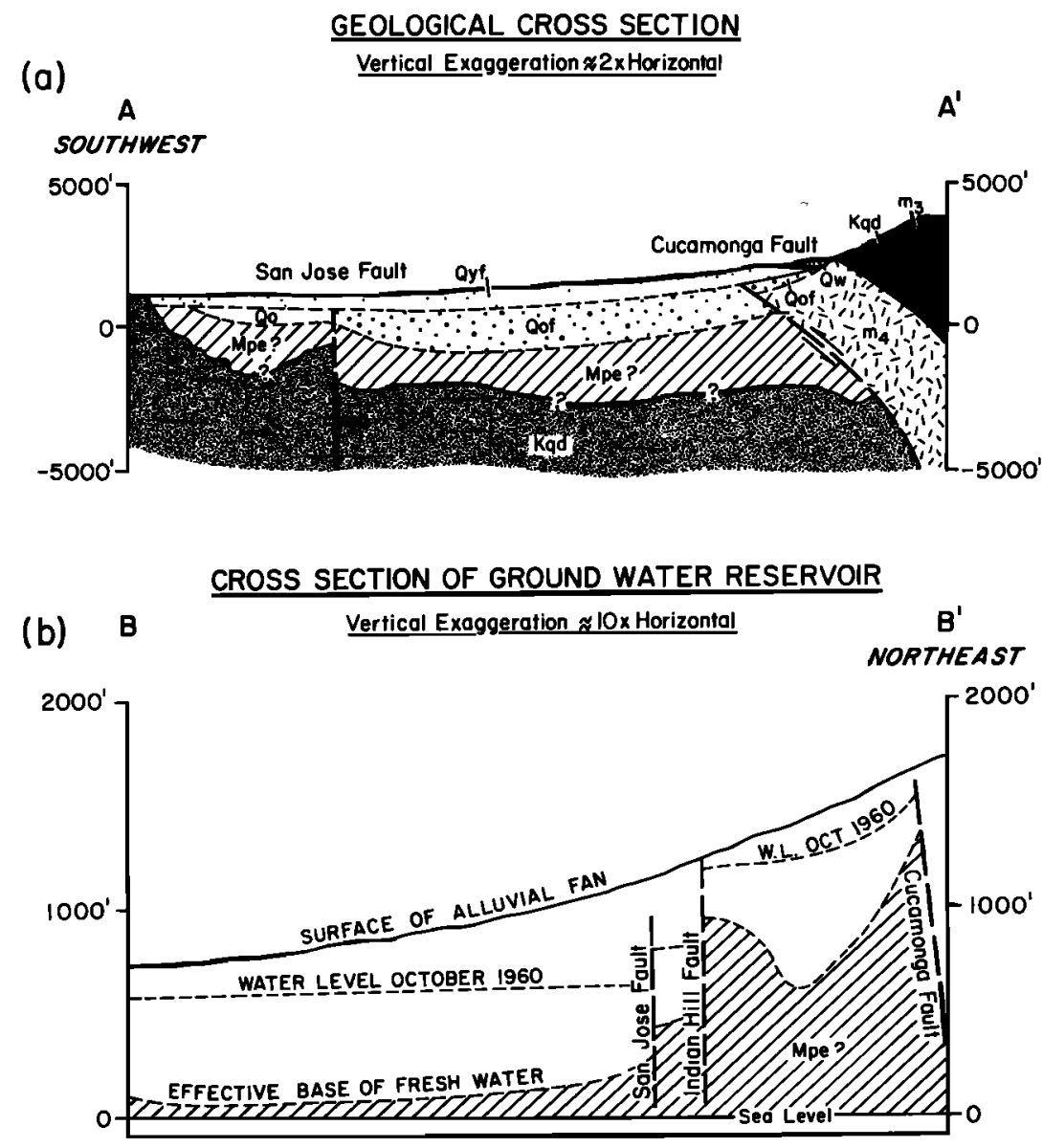

Fig. 3. (a) Geologic cross section along the line A-A' (in Figure 2a), from Bortugno and Spittler [1986]. Rock types are Qyf, younger fan deposits; Qo, older alluvium (undifferentiated); Qof, older fan deposits; Mpe, Puente formation (marine siltstone, sandstone, and shale); Kqd, Cretaceous quartz diorite; Qw, wash deposits (alluvial deposits of modem washes); $\mathrm{m} 4$, high-grade metamorphic rocks; and $\mathrm{m} 3$, "black belt" mylonite. (b) Cross section showing the top of the water table and effective base of the groundwater reservoir along the line B-B' shown in Figure 2a, from California DWR, [1970].

Figure 1). The four largest earthquakes occurred in 1986 , 1988, and 1989. The two 1986 events $\left(M_{L}=3.0\right.$ and $M_{L}=3.3$ ) had thrust and strike-slip focal mechanisms (Figure 5). The 1986 thrust event cannot be associated with a specific fault. The 1986 left-lateral strike-slip event $\left(M_{L}=3.0\right)$ may be associated with a northeast striking segment of the Cucamonga fault. To the south a $M_{L}=4.3$ mainshock that occurred near the Chino fault in 1989 showed right-lateral strike-slip motion on the Chino fault and was followed by several aftershocks.

Although evident in the subsurface geology, the San Jose fault is not clearly delineated by the background seismicity. The only nearby cluster of small earthquakes $\left(M_{L}<2.5\right)$ is located between the overlap of the Walnut Creek fault and the southwestern end of the San Jose fault. In cross section C-C' (Figure 5c) a line is projected from the surface trace of the San Jose fault to these hypocenters. This suggests a maximum dip of $85^{\circ}$ to the north along the southem segment of the San Jose fault. This cluster is also bracketed to the east by the Chino fault (Figure $5 d$ ). Although seismicity in this area has been closely monitored over the last decade by the USGS/CIT seismic network, prior to 1988 no clear seismicity patterns could be identified adjacent to the San Jose fault.

\section{The 1988 Upland Sequence}

The 1988 mainshock-aftershock sequence formed the first prominent seismicity pattern in the Upland region (Figure 5). The $M_{L}=4.6$ Upland mainshock occurred at 1504 UT on June 26,1988 , at $34^{\circ} 7.8 \mathrm{~N}, 117^{\circ} 42.4^{\prime} \mathrm{W}$. The spatial distribution of hypocenters of the mainshock and aftershocks shows that the sequence occurred on the San Jose fault. The 1988 aftershock zone had an approximate length of 1 to $2 \mathrm{~km}$ to the northeast and extended from 10 to $4 \mathrm{~km}$ depth (Figure $5 b$ ). The short length as compared with the 4 times larger depth range is unusual and suggests that this relatively small mainshock did not have a circular rupture.

The focal mechanism of the mainshock had one nodal plane striking parallel to the San Jose fault and dipping $40^{\circ}-50^{\circ}$ to the north. The dip of this plane is inconsistent with the dip of the aftershock zone in the depth range from 10 to $4 \mathrm{~km}$, which is steeper than $70^{\circ}$, the presumed 

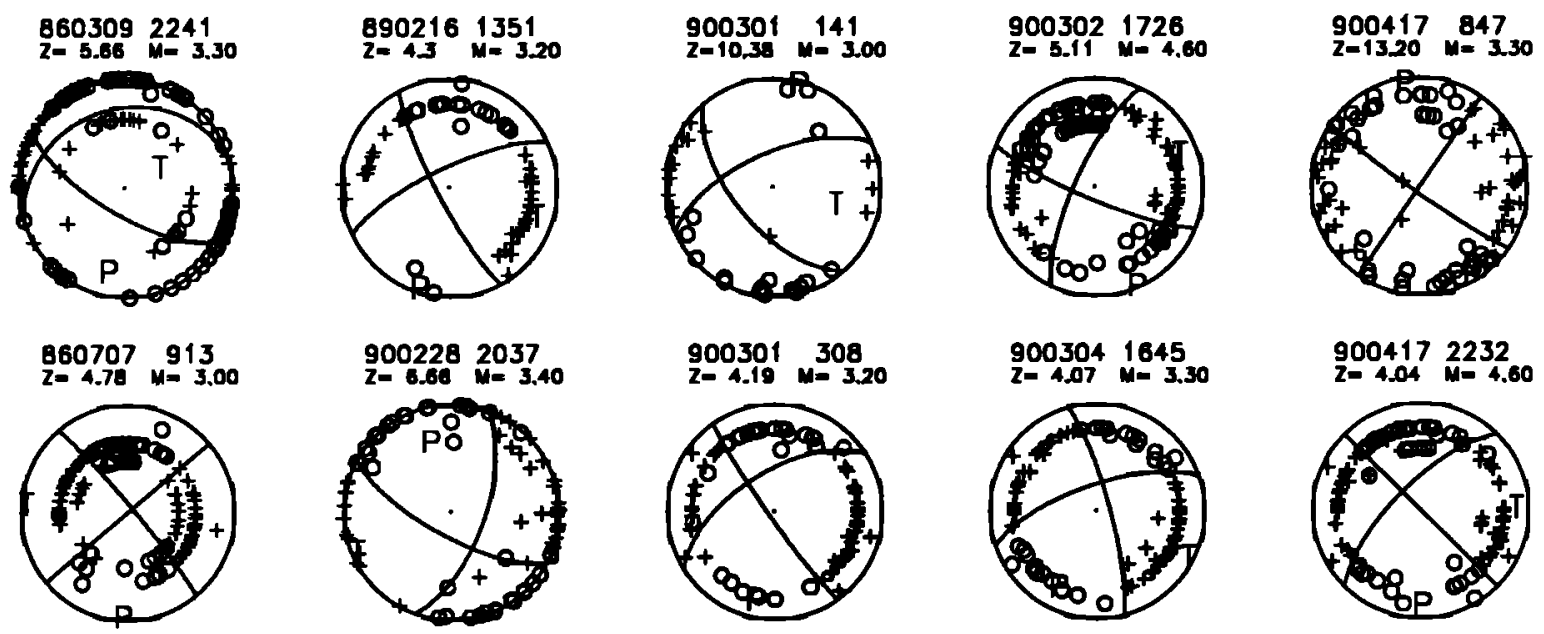

9004172232
$2=4.04$
$M$
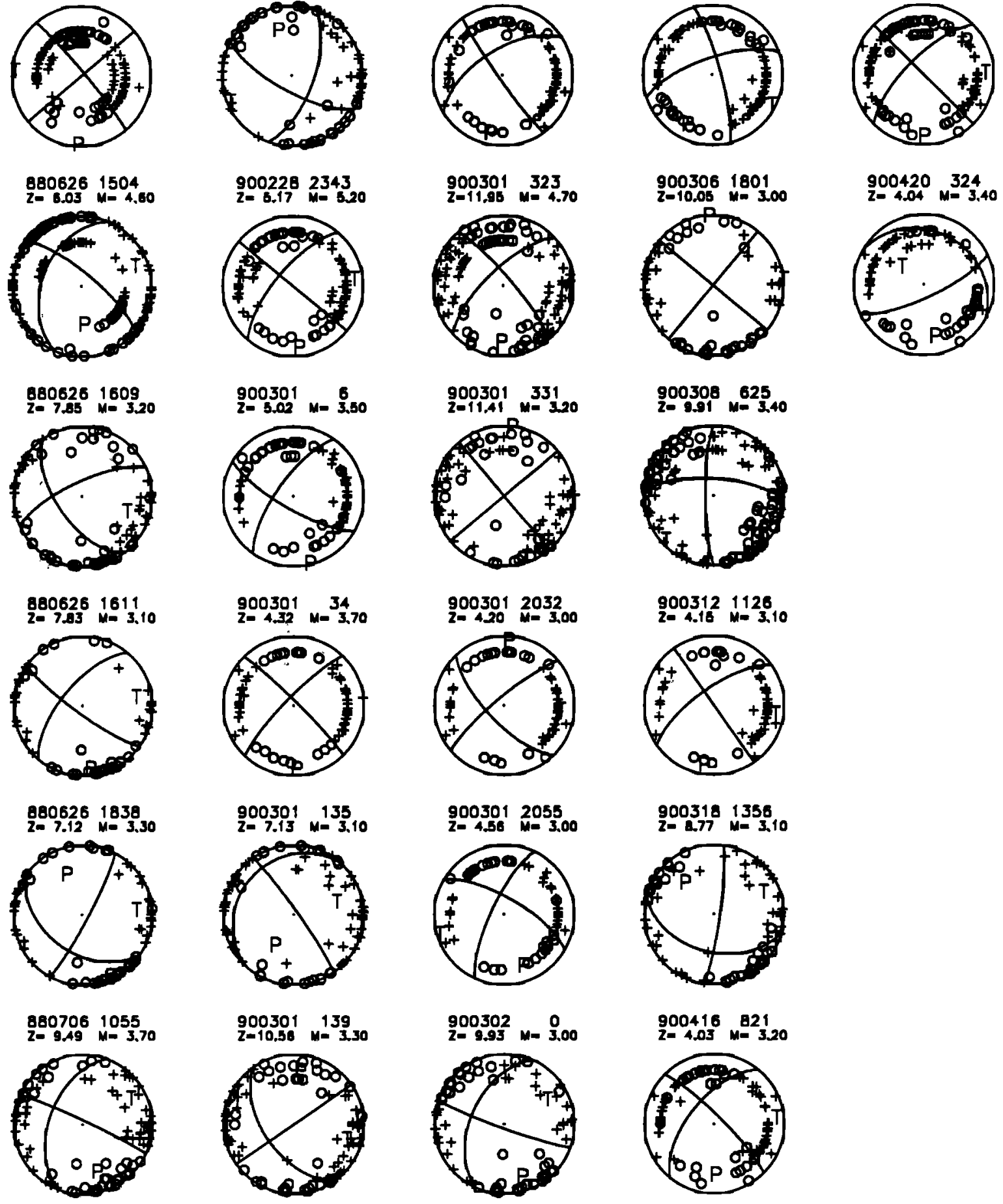

Fig. 4. Single-event, lower hemisphere focal mechanisms for $M_{L} \geq 3.0$ background earthquakes, foreshock, and aftershocks in 1988 and 1990 . Compressional first motions are shown by pluses and dilational first motions by open circles. 
TABLE 1. Locations and Focal Mechanisms of Earthquakes in the Upland Area

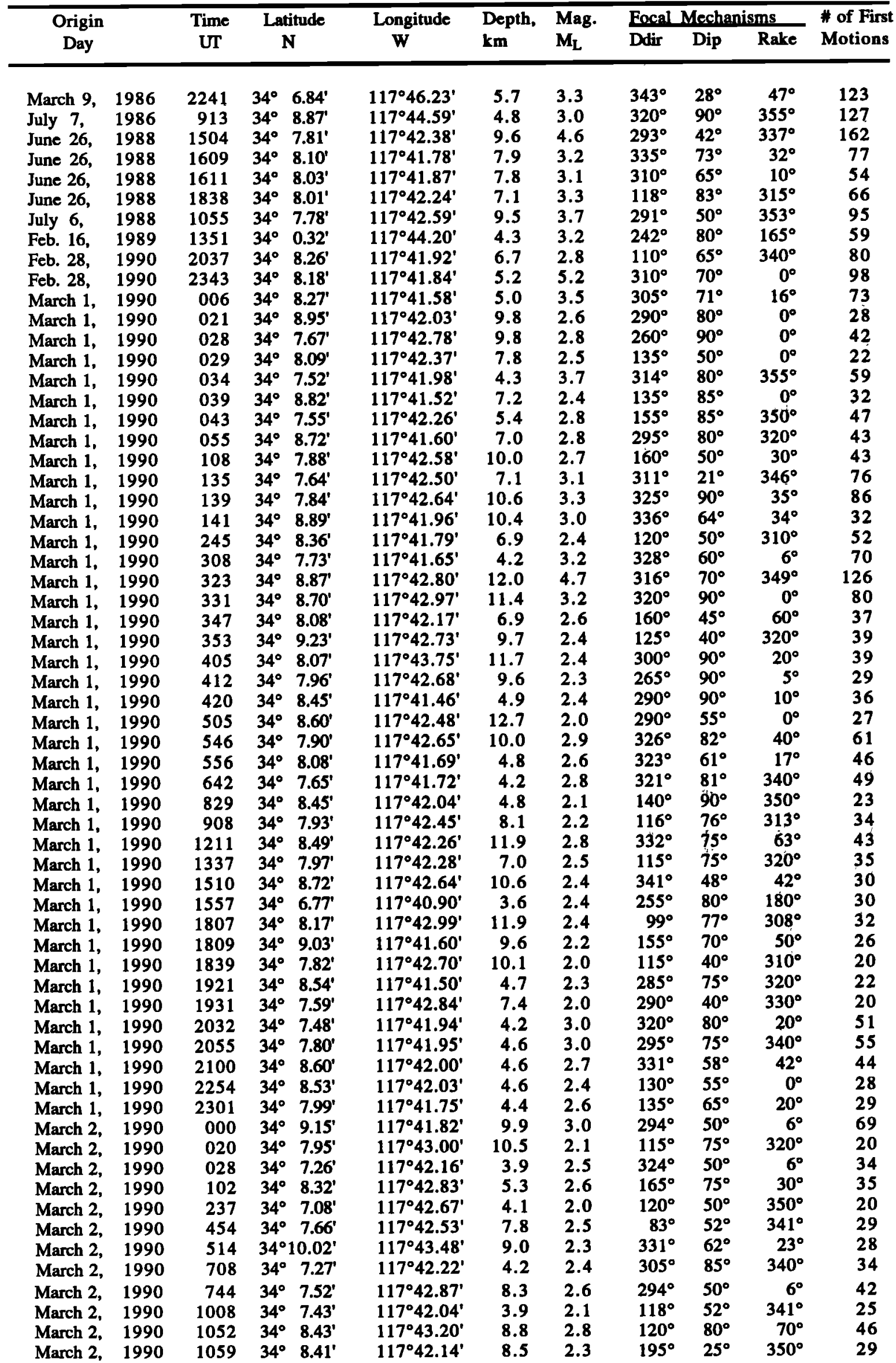


TABLE 1. (continued)

\begin{tabular}{|c|c|c|c|c|c|c|c|c|c|c|c|}
\hline \multirow{2}{*}{\multicolumn{2}{|c|}{$\begin{array}{c}\text { Origin } \\
\text { Day }\end{array}$}} & \multirow{3}{*}{$\begin{array}{c}\begin{array}{c}\text { Time } \\
\text { UT }\end{array} \\
1313\end{array}$} & \multirow{2}{*}{\multicolumn{2}{|c|}{$\begin{array}{l}\text { Latitude } \\
\qquad \mathbf{N}\end{array}$}} & \multirow{4}{*}{$\begin{array}{l}\text { Longitude } \\
\mathrm{W}\end{array}$} & \multirow{3}{*}{$\begin{array}{c}\text { Depth, } \\
\text { km } \\
9.4\end{array}$} & \multirow{3}{*}{$\begin{array}{l}\text { Mag. } \\
M_{L} \\
2.6\end{array}$} & \multicolumn{3}{|c|}{ Focal Mechanisms } & \multirow{2}{*}{$\begin{array}{l}\text { \# of Firs } \\
\text { Motions }\end{array}$} \\
\hline & & & & & & & & Ddir & Dip & Rake & \\
\hline March 2, & 1990 & & $34^{\circ}$ & $7.83^{\prime}$ & & & & $165^{\circ}$ & $60^{\circ}$ & $70^{\circ}$ & 22 \\
\hline March 2, & 1990 & 1610 & $34^{\circ}$ & 7.77 & & 7.9 & 2.3 & $115^{\circ}$ & $70^{\circ}$ & $310^{\circ}$ & 22 \\
\hline March 2, & 1990 & 1726 & $34^{\circ}$ & $8.66^{\prime}$ & $117^{\circ} 41.43^{\prime}$ & 5.1 & 4.6 & $295^{\circ}$ & $75^{\circ}$ & $10^{\circ}$ & 132 \\
\hline March 2, & 1990 & 1828 & $34^{\circ}$ & 8.32 & $117^{\circ} 41.41^{\prime}$ & 4.6 & 2.5 & $311^{\circ}$ & $40^{\circ}$ & $8^{\circ}$ & 40 \\
\hline March 2, & 1990 & 1841 & $34^{\circ}$ & 7.58 & $117^{\circ} 42.11^{\prime}$ & 4.5 & 2.5 & $150^{\circ}$ & $80^{\circ}$ & $350^{\circ}$ & 53 \\
\hline March 2, & 1990 & 2026 & $34^{\circ}$ & $8.73^{\prime}$ & $117^{\circ} 41.90^{\prime}$ & 8.7 & 2.7 & $301^{\circ}$ & $63^{\circ}$ & $332^{\circ}$ & 61 \\
\hline March 2, & 1990 & 2038 & $34^{\circ}$ & 8.27 & $117^{\circ} 42.15^{\prime}$ & 7.5 & 2.5 & $115^{\circ}$ & $65^{\circ}$ & $30^{\circ}$ & 41 \\
\hline March 2, & 1990 & 2203 & $34^{\circ}$ & $9.06^{\prime}$ & $117^{\circ} 41.91^{\prime}$ & 9.4 & 2.2 & $304^{\circ}$ & $33^{\circ}$ & $28^{\circ}$ & 33 \\
\hline March 2, & 1990 & 2359 & $34^{\circ}$ & 8.86' & $117^{\circ} 42.47^{\prime}$ & 10.3 & 2.1 & $311^{\circ}$ & $58^{\circ}$ & $42^{\circ}$ & 22 \\
\hline March 3, & 1990 & 136 & $34^{\circ}$ & $7.93^{\prime}$ & $117^{\circ} 43.29^{\prime}$ & 11.0 & 2.3 & $19^{\circ}$ & $70^{\circ}$ & $86^{\circ}$ & 32 \\
\hline March 3, & 1990 & 155 & $34^{\circ}$ & $7.65^{\prime}$ & $117^{\circ} 42.51^{\prime}$ & 6.2 & 2.1 & $145^{\circ}$ & $50^{\circ}$ & $10^{\circ}$ & 39 \\
\hline March 3, & 1990 & 314 & $34^{\circ}$ & $8.42^{\prime}$ & $117^{\circ} 41.23^{\prime}$ & 4.7 & 2.1 & $309^{\circ}$ & $64^{\circ}$ & $66^{\circ}$ & 20 \\
\hline March 3, & 1990 & 351 & $34^{\circ}$ & $7.42^{\prime}$ & $117^{\circ} 41.91^{\prime}$ & 3.9 & 2.1 & $305^{\circ}$ & $70^{\circ}$ & $340^{\circ}$ & 22 \\
\hline March 3, & 1990 & 548 & $34^{\circ}$ & $8.13^{\prime}$ & $117^{\circ} 42.20^{\prime}$ & 7.3 & 2.2 & $81^{\circ}$ & $85^{\circ}$ & $300^{\circ}$ & 39 \\
\hline March 3, & 1990 & 1659 & $34^{\circ}$ & 7.12 & $117^{\circ} 42.64^{\prime}$ & 4.1 & 2.2 & $310^{\circ}$ & $90^{\circ}$ & $55^{\circ}$ & 29 \\
\hline March 3, & 1990 & 2321 & $34^{\circ}$ & $6.96^{\prime}$ & $117^{\circ} 40.85^{\prime}$ & 4.3 & 2.3 & $255^{\circ}$ & $90^{\circ}$ & $160^{\circ}$ & 32 \\
\hline March 4, & 1990 & 541 & $34^{\circ}$ & $8.96^{\prime}$ & $117^{\circ} 42.20^{\prime}$ & 11.0 & 2.2 & $133^{\circ}$ & $80^{\circ}$ & $15^{\circ}$ & 22 \\
\hline March 4, & 1990 & 630 & $34^{\circ}$ & $7.55^{\prime}$ & $117^{\circ} 42.16^{\prime}$ & 3.4 & 2.0 & $135^{\circ}$ & $65^{\circ}$ & $10^{\circ}$ & 10 \\
\hline March 4, & 1990 & 1507 & $34^{\circ}$ & $6.77^{\prime}$ & $117^{\circ} 40.80^{\prime}$ & 3.9 & 2.7 & $250^{\circ}$ & $90^{\circ}$ & $180^{\circ}$ & 49 \\
\hline March 4, & 1990 & 1625 & $34^{\circ}$ & $6.78^{\prime}$ & $117^{\circ} 40.77^{\prime}$ & 4.0 & 2.4 & $262^{\circ}$ & $81^{\circ}$ & $160^{\circ}$ & 31 \\
\hline March 4, & 1990 & 1645 & $34^{\circ}$ & $6.94^{\prime}$ & $117^{\circ} 40.87^{\prime}$ & 4.1 & 3.3 & $75^{\circ}$ & $80^{\circ}$ & $200^{\circ}$ & 84 \\
\hline March 4, & 1990 & 1715 & $34^{\circ}$ & $6.62^{\prime}$ & $117^{\circ} 40.73^{\prime}$ & 4.1 & 2.3 & $248^{\circ}$ & $70^{\circ}$ & $175^{\circ}$ & 25 \\
\hline March 4, & 1990 & 2022 & $34^{\circ}$ & $8.39^{\prime}$ & $117^{\circ} 41.23^{\prime}$ & 4.6 & 2.0 & $282^{\circ}$ & $79^{\circ}$ & $57^{\circ}$ & 20 \\
\hline March 5, & 1990 & 1928 & $34^{\circ}$ & $7.88^{\prime}$ & $117^{\circ} 41.49^{\prime}$ & 4.1 & 2.3 & $125^{\circ}$ & $50^{\circ}$ & $350^{\circ}$ & 26 \\
\hline March 6, & 1990 & 1801 & $34^{\circ}$ & $9.15^{\prime}$ & $117^{\circ} 41.59^{\prime}$ & 10.1 & 3.0 & $310^{\circ}$ & $90^{\circ}$ & $0^{\circ}$ & 54 \\
\hline March 7, & 1990 & 2118 & $34^{\circ}$ & $7.87^{\prime}$ & $117^{\circ} 42.67^{\prime}$ & 10.6 & 2.3 & $170^{\circ}$ & $55^{\circ}$ & $20^{\circ}$ & 29 \\
\hline March 8, & 1990 & 625 & $34^{\circ}$ & $7.61^{\prime}$ & $117^{\circ} 42.72^{\prime}$ & 9.9 & 3.4 & $270^{\circ}$ & $80^{\circ}$ & $340^{\circ}$ & 113 \\
\hline March 10, & 1990 & 232 & $34^{\circ}$ & $8.93^{\prime}$ & $117^{\circ} 43.68^{\prime}$ & 7.3 & 2.2 & $113^{\circ}$ & $79^{\circ}$ & $303^{\circ}$ & 21 \\
\hline March 10, & 1990 & 729 & $34^{\circ}$ & $\mathbf{8 . 8 2}$ & $117^{\circ} 42.81^{\prime}$ & 12.9 & 2.0 & $290^{\circ}$ & $45^{\circ}$ & $330^{\circ}$ & 20 \\
\hline March 10, & 1990 & 1745 & $34^{\circ}$ & $7.20^{\prime}$ & $117^{\circ} 42.27^{\prime}$ & 3.8 & 2.1 & $141^{\circ}$ & $81^{\circ}$ & $335^{\circ}$ & 22 \\
\hline March 10, & 1990 & 1918 & $34^{\circ}$ & $7.16^{\prime}$ & $117^{\circ} 42.29^{\prime}$ & 3.8 & 2.1 & $135^{\circ}$ & $70^{\circ}$ & $340^{\circ}$ & 21 \\
\hline March 10, & 1990 & 2054 & $34^{\circ}$ & $7.16^{\prime}$ & $117^{\circ} 42.26^{\prime}$ & 3.7 & 2.2 & $330^{\circ}$ & $73^{\circ}$ & $32^{\circ}$ & 26 \\
\hline March 11, & 1990 & 1033 & $34^{\circ}$ & $7.53^{\prime}$ & $117^{\circ} 41.75^{\prime}$ & 7.5 & 2.1 & $155^{\circ}$ & $75^{\circ}$ & $350^{\circ}$ & 23 \\
\hline March 12, & 1990 & 904 & $34^{\circ}$ & $7.61^{\prime}$ & $117^{\circ} 41.71^{\prime}$ & 4.0 & 2.3 & $325^{\circ}$ & $65^{\circ}$ & $20^{\circ}$ & 26 \\
\hline March 12, & 1990 & 1126 & $34^{\circ}$ & $7.51^{\prime}$ & $117^{\circ} 41.83^{\prime}$ & 4.2 & 3.1 & $325^{\circ}$ & $70^{\circ}$ & $0^{\circ}$ & 52 \\
\hline h 12 , & 1990 & 1129 & $34^{\circ}$ & $7.45^{\prime}$ & $117^{\circ} 41.91^{\prime}$ & 4.0 & 2.8 & $327^{\circ}$ & $71^{\circ}$ & $21^{\circ}$ & 40 \\
\hline March 13, & 1990 & 710 & $34^{\circ}$ & 7.04' & $117^{\circ} 43.22^{\prime}$ & 4.4 & 2.5 & $140^{\circ}$ & $70^{\circ}$ & $350^{\circ}$ & 38 \\
\hline March 15, & 1990 & 110 & $34^{\circ}$ & 7.82' & $117^{\circ} 42.33^{\prime}$ & 4.6 & 2.1 & $160^{\circ}$ & $60^{\circ}$ & $30^{\circ}$ & 27 \\
\hline March 15, & 1990 & 1732 & $34^{\circ}$ & 9.84' & $117^{\circ} 43.76^{\prime}$ & 10.0 & 2.0 & $335^{\circ}$ & $50^{\circ}$ & $0^{\circ}$ & 30 \\
\hline March 17, & 1990 & 1655 & $34^{\circ}$ & 8.62' & $117^{\circ} 43.03^{\prime}$ & 5.4 & 2.0 & $330^{\circ}$ & $90^{\circ}$ & $10^{\circ}$ & 22 \\
\hline March 18, & 1990 & 1356 & $34^{\circ}$ & 8.54' & $117^{\circ} 42.35^{\prime}$ & 8.8 & 3.1 & $98^{\circ}$ & $83^{\circ}$ & $315^{\circ}$ & 73 \\
\hline March 19, & 1990 & 910 & $34^{\circ}$ & $7.70^{\prime}$ & $117^{\circ} 42.81^{\prime}$ & 9.2 & 2.1 & $95^{\circ}$ & $75^{\circ}$ & $40^{\circ}$ & 28 \\
\hline March 25, & 1990 & 906 & $34^{\circ}$ & 8.22' & $117^{\circ} 42.64^{\prime}$ & 8.6 & 2.5 & $346^{\circ}$ & $82^{\circ}$ & $40^{\circ}$ & 57 \\
\hline March 26, & 1990 & 2016 & $34^{\circ}$ & $9.29^{\prime}$ & $117^{\circ} 41.87^{\prime}$ & 9.5 & 2.4 & $293^{\circ}$ & $75^{\circ}$ & $42^{\circ}$ & 37 \\
\hline March 28, & 1990 & 1438 & $34^{\circ}$ & $9.02^{\prime}$ & $117^{\circ} 42.00^{\prime}$ & 10.2 & 2.5 & $115^{\circ}$ & $75^{\circ}$ & $330^{\circ}$ & 34 \\
\hline March 28, & 1990 & 2023 & $34^{\circ}$ & $9.10^{\prime}$ & $117^{\circ} 41.96^{\prime}$ & 10.1 & 2.0 & $135^{\circ}$ & $50^{\circ}$ & $350^{\circ}$ & 25 \\
\hline March 29, & 1990 & 2101 & $34^{\circ}$ & $7.36^{\prime}$ & $117^{\circ} 42.41^{\prime}$ & 4.2 & 2.1 & $358^{\circ}$ & $75^{\circ}$ & $297^{\circ}$ & 30 \\
\hline April 2, & 1990 & 342 & $34^{\circ}$ & $4.91^{\circ}$ & $117^{\circ} 47.67^{\prime}$ & 14.7 & 2.2 & $139^{\circ}$ & $60^{\circ}$ & $348^{\circ}$ & 36 \\
\hline April 3, & 1990 & 1035 & $34^{\circ}$ & $7.94^{\prime}$ & $117^{\circ} 41.40^{\prime}$ & 4.2 & 2.0 & $135^{\circ}$ & $80^{\circ}$ & $350^{\circ}$ & 20 \\
\hline April 6, & 1990 & 113 & $34^{\circ}$ & $8.44^{\prime}$ & $117^{\circ} 41.90^{\prime}$ & 6.9 & 2.3 & $290^{\circ}$ & $80^{\circ}$ & $0^{\circ}$ & 25 \\
\hline April 9, & 1990 & 450 & $34^{\circ}$ & $8.10^{\prime}$ & $117^{\circ} 43.54^{\prime}$ & 11.1 & 2.1 & $310^{\circ}$ & $80^{\circ}$ & $10^{\circ}$ & 29 \\
\hline April 9, & 1990 & 636 & $34^{\circ}$ & $9.93^{\prime}$ & $117^{\circ} 42.43^{\prime}$ & 2.5 & 2.0 & $315^{\circ}$ & $90^{\circ}$ & $35^{\circ}$ & 22 \\
\hline April 9, & 1990 & 2039 & $34^{\circ} 1$ & $0.07^{\prime}$ & $117^{\circ} 43.28^{\prime}$ & 9.4 & 2.2 & $145^{\circ}$ & $70^{\circ}$ & $340^{\circ}$ & 24 \\
\hline April 11, & 1990 & 1911 & $34^{\circ}$ & $8.59^{\prime}$ & $117^{\circ} 41.85^{\prime}$ & 7.5 & 2.2 & $348^{\circ}$ & $71^{\circ}$ & $339^{\circ}$ & 26 \\
\hline April 13, & 1990 & 1320 & $34^{\circ}$ & $7.94^{\prime}$ & $117^{\circ} 42.01^{\prime}$ & 4.6 & 2.1 & $130^{\circ}$ & $80^{\circ}$ & $350^{\circ}$ & 27 \\
\hline April 16, & 1990 & 821 & $34^{\circ}$ & $6.25^{\prime}$ & $117^{\circ} 43.30^{\prime}$ & 4.0 & 3.2 & $309^{\circ}$ & $60^{\circ}$ & $348^{\circ}$ & 87 \\
\hline April 16, & 1990 & 824 & $34^{\circ}$ & $6.38^{\prime}$ & $117^{\circ} 43.11^{\prime}$ & 4.1 & 2.4 & $315^{\circ}$ & $80^{\circ}$ & $350^{\circ}$ & 31 \\
\hline April 17, & 1990 & 847 & $34^{\circ}$ & $9.41^{\prime}$ & $117^{\circ} 43.67^{\prime}$ & 13.2 & 3.3 & $305^{\circ}$ & $90^{\circ}$ & $5^{\circ}$ & 88 \\
\hline April 17, & 1990 & 1419 & $34^{\circ}$ & $6.25^{\prime}$ & $117^{\circ} 43.21^{\prime}$ & 4.0 & 2.6 & $315^{\circ}$ & $80^{\circ}$ & $0^{\circ}$ & 32 \\
\hline April 17, & 1990 & 2232 & $34^{\circ}$ & $6.23^{\prime}$ & $117^{\circ} 43.19^{\prime}$ & 4.0 & 4.6 & $315^{\circ}$ & $70^{\circ}$ & $0^{\circ}$ & 106 \\
\hline April 17, & 1990 & 2332 & $34^{\circ}$ & $6.09^{\prime}$ & $117^{\circ} 43.13^{\prime}$ & 3.7 & 2.5 & $322^{\circ}$ & $42^{\circ}$ & $23^{\circ}$ & 37 \\
\hline April 18, & 1990 & 035 & $34^{\circ}$ & $6.10^{\prime}$ & $117^{\circ} 43.41^{\prime}$ & 3.9 & 2.5 & $319^{\circ}$ & $80^{\circ}$ & $355^{\circ}$ & 43 \\
\hline April 18, & 1990 & 129 & $34^{\circ}$ & $6.50^{\prime}$ & $117^{\circ} 43.08^{\prime}$ & 4.1 & 2.2 & $140^{\circ}$ & $65^{\circ}$ & $80^{\circ}$ & 20 \\
\hline
\end{tabular}


TABLE 1. (continued)

\begin{tabular}{|c|c|c|c|c|c|c|c|c|c|c|c|}
\hline \multirow{2}{*}{\multicolumn{2}{|c|}{$\begin{array}{c}\text { Origin } \\
\text { Day }\end{array}$}} & \multirow{3}{*}{$\begin{array}{c}\begin{array}{c}\text { Time } \\
\text { UT }\end{array} \\
1126\end{array}$} & \multirow{2}{*}{\multicolumn{2}{|c|}{$\begin{array}{l}\text { Latitude } \\
\text { N }\end{array}$}} & \multirow{2}{*}{$\begin{array}{l}\text { Longitude } \\
\mathbf{W}\end{array}$} & \multirow{2}{*}{$\begin{array}{l}\text { Depth, } \\
\text { km }\end{array}$} & \multirow{2}{*}{$\begin{array}{l}\text { Mag. } \\
\mathbf{M}_{\mathbf{L}}\end{array}$} & \multicolumn{3}{|c|}{ Focal Mechanisms } & \multirow{2}{*}{$\begin{array}{l}\text { \# of First } \\
\text { Motions }\end{array}$} \\
\hline & & & & & & & & Ddir & Dip & Rake & \\
\hline April 18, & 1990 & & $34^{\circ}$ & $5.90^{\prime}$ & $117^{\circ} 43.47^{\prime}$ & 3.8 & 2.5 & $322^{\circ}$ & $42^{\circ}$ & $23^{\circ}$ & 38 \\
\hline April 18, & 1990 & 2023 & $34^{\circ}$ & 7.86' & $117^{\circ} 42.90^{\prime}$ & 10.3 & 2.0 & $155^{\circ}$ & $55^{\circ}$ & $350^{\circ}$ & 33 \\
\hline April 19, & 1990 & 453 & $34^{\circ}$ & $6.24^{\prime}$ & $117^{\circ} 43.44^{\prime}$ & 4.2 & 2.0 & $143^{\circ}$ & $80^{\circ}$ & $15^{\circ}$ & 25 \\
\hline April 19, & 1990 & 2253 & $34^{\circ}$ & 6.61 & $117^{\circ} 43.23^{\prime}$ & 4.2 & 2.1 & $131^{\circ}$ & $70^{\circ}$ & $349^{\circ}$ & 26 \\
\hline April 20, & 1990 & 324 & $34^{\circ}$ & 6.72' & $117^{\circ} 43.16^{\prime}$ & 4.0 & 3.4 & $155^{\circ}$ & $7^{\circ}$ & $70^{\circ}$ & 72 \\
\hline May 9 , & 1990 & 2129 & $34^{\circ}$ & $6.04^{\prime}$ & $117^{\circ} 43.58^{\prime}$ & 4.2 & 2.5 & $150^{\circ}$ & $60^{\circ}$ & $90^{\circ}$ & 23 \\
\hline
\end{tabular}

average dip of the San Jose fault. A couple of deep aftershocks to 1988 suggest that the dip is shallower below the 1988 mainshock, which was again borne out by the aftershocks to the 1990 mainshock.

The apparent inconsistency between the 1988 mainshock focal mechanism and the hypocentral distribution of its aftershocks suggests that the rupture started on the deeper and more gently dipping part of the San Jose fault and almost immediately advanced upward onto the more steeply dipping part of the fault where most of the aftershocks occurred. Alternatively, the shallower aftershocks could be occurring above the rupture surface of the mainshock as suggested by the results of Mori and Hartzell [1990] who modeled the mainshock as having a rupture area of only $0.96 \mathrm{~km}^{2}$.

The distribution of seismicity along strike of the San Jose fault is shown in Figure $5 d$. For reference, three zones are outlined with dashed lines and labeled A, B, and $\mathrm{C}$ in the cross section in Figure $5 d$ The zone labeled $A$ is the aftershock zone of the 1988 earthquake. Zones A and B together are the aftershock zone of the 1990 sequence. The zone labeled $C$ is the presently aseismic segment, which may cause the next moderate-sized earthquake. The upper and lower depth limits of 5 and $12 \mathrm{~km}$, respectively, are chosen somewhat arbitrarily to outline the aseismic zone C. The cluster of events at $5 \mathrm{~km}$ depth in the middle of the cross-section D-D' are probably not related to the San Jose fault, as discussed above, although they project into its plane. The distribution of 1988 aftershocks and the scattered background seismicity along the strike of the San Jose fault thus formed a prominent seismicity pattern and already suggested the importance of the San Jose fault as a seismogenic structure.

\section{The 1990 Upland Sequence}

The 1990 mainshock. The $M_{L}=5.2$ Upland mainshock occurred at 2343 UT on February 28, 1990, at 34 $8.2^{\prime} \mathrm{N}$, $117^{\circ} 41.8^{\prime} \mathrm{W}$ and a depth of $5.2 \mathrm{~km}$ (Figure 6). No surface offsets were found on any faults in the vicinity (K. Sieh and D. Morton, personal communication, 1990). The mainshock focal mechanism showed pure left-lateral strike slip (a rake of $0^{\circ}$ ) with a dip of $70^{\circ}$ on a fault striking $\mathrm{N} 40^{\circ} \mathrm{E}$.

The first-day aftershock locations show a northeast trend of activity extending for approximately $1.5-2.0 \mathrm{~km}$ to the southwest and $1.5-2.0 \mathrm{~km}$ to the northeast from the mainshock epicenter, consistent with bilateral rupture on a northeast striking fault. The aftershock zone projects up to the surface trace of the San Jose fault (Figures $6 b$ and $6 c$ ). A small cluster of off-fault aftershocks occurred to the southeast of the mainshock. Six weeks after the mainshock, the aftershock activity in the depth range of 3-5 $\mathrm{km}$ extended $4-5 \mathrm{~km}$ to the southwest (Figures $6 a$ and $6 d$ ).

Foreshocks. The mainshock was preceded by a $M_{L}=3.6$ foreshock that occurred at 2037 UT and was located less than a kilometer away from the epicenter of the mainshock. This foreshock was followed by only two aftershocks in the magnitude range of 1.5-2.0 (Figure 7a). The foreshock preceded the mainshock by 3.1 hours and occurred at a depth of $6.7 \mathrm{~km}, 1.5 \mathrm{~km}$ deeper than the mainshock. The foreshock had a focal mechanism that was different from the mainshock mechanism with a nodal plane striking $\mathrm{N} 20^{\circ} \mathrm{E}$ and dipping $65^{\circ}$ to the east, unlike the mainshock that dips $70^{\circ}$ to the west (Figure 6). The rake is $-20^{\circ}$, indicating a slight normal component with the southeast side being the down-dropped block.

By comparison, the 1988 mainshock was not preceded by any foreshocks (Figure $7 b$ ). It was also followed by proportionally fewer aftershocks because the mainshock magnitude was smaller.

Distribution of aftershocks. Three cross sections are shown in Figure 6. The first cross section, $A-A^{\prime}$, in Figure $6 b$ includes hypocenters located within a rectangular box that extends $4 \mathrm{~km}$ northeast of the line A-A'. The second cross section in Figure 6c shows hypocenters located within a rectangular box extending $4 \mathrm{~km}$ to the southwest of the line A-A'. The third cross section, B-B', in Figure 6d is parallel to the fault and shows the distribution of aftershocks projected onto the fault surface itself. The three zones A, B and C of Figure 5 are also marked on this cross section.

The hypocenters of the aftershocks clearly delineate the plane on which the earthquake occurred. Northeast of A-A' (Figure $6 b$ ), the hypocenters define a tight zone striking northeast and dipping $70^{\circ}$ to the northwest. Southwest of A-A' (Figure $6 c$ ), the aftershock zone still strikes northeast but is almost vertical above $9 \mathrm{~km}$ depth and then forms a broad zone in the depth range of 9-12 km, suggesting complex three-dimensional geometry of faulting at depth. Most of the aftershocks are located on or adjacent to the main plane with one notable exception. A small cluster of aftershocks occurred within the first 2 days of the sequence $2 \mathbf{k m}$ southeast of the main plane. This cluster forms a northerly strike, and the largest earthquake in this cluster was $M_{L}=3.3$ (Figure 6a). These off-fault aftershocks may 
Upland 1981-1989
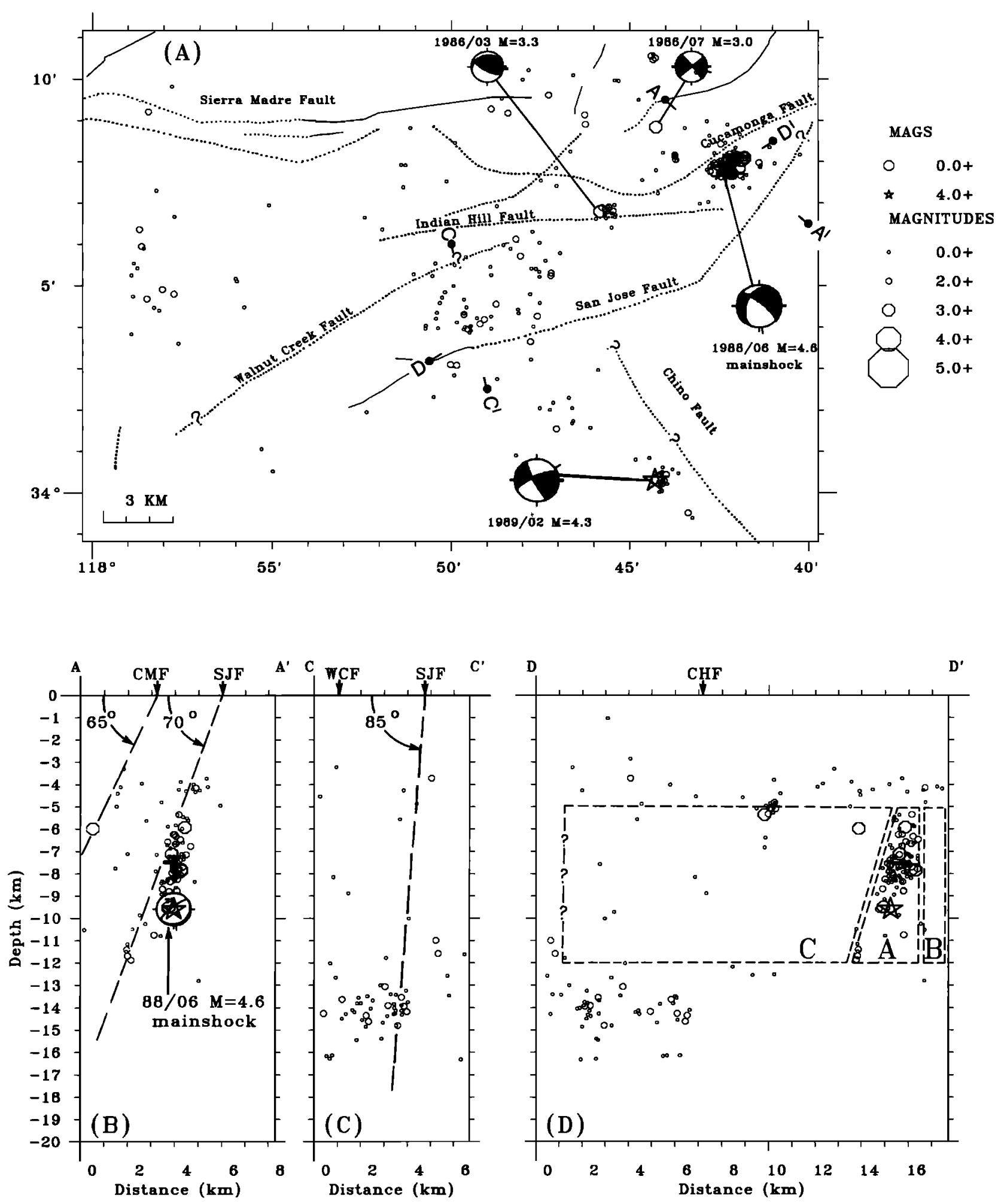

Fig. 5. Earthquakes recorded by the Southern California Seismic Network between 1981 and 1989. (a) A map showing earthquake epicenters, active faults (dotted where inferred) from Jennings [1975], and focal mechanisms of $M_{L} \geq 3.0$ earthquakes. Also shown are end points A-A', C-C', and D-D'. (b) The earthquake hypocenters within $4 \mathrm{~km}$ of the line $A-A^{\prime}$ projected onto the line. Dashed lines are projected at $65^{\circ}$ and $70^{\circ}$ from the surface traces of the Cucamonga and San Jose faults, respectively. (c) The earthquake hypocenters within $5 \mathrm{~km}$ of the line C-C' projected onto the line. Dashed line is projected at $85^{\circ}$ from the surface trace of the San Jose fault. (d) The earthquake hypocenters within $6 \mathrm{~km}$ of the line D-D' projected onto the line, along strike of the San Jose fault. Three zones are outlined: the aftershock zone of 1988 (A), the aftershock zone of 1990 (A and B), and the aseismic zone (C). 
Upland 28 February 1990 - 31 May 1990
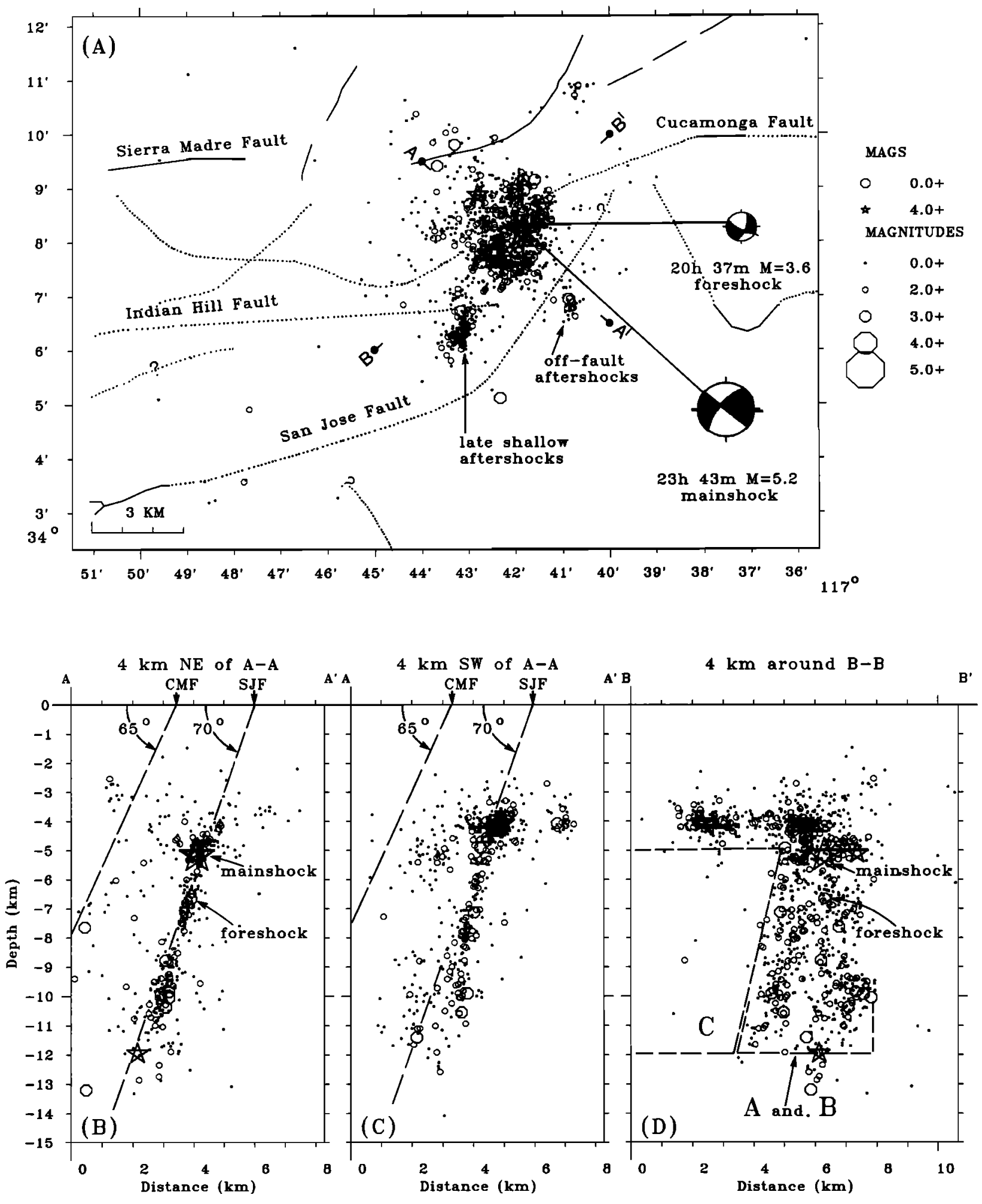

Fig. 6. The foreshock-mainshock-aftershock sequence of the 1990 Upland earthquake recorded by the Southem Califomia Seismic Network. (a) A map showing earthquake epicenters, active faults as in Figure 5 , and focal mechanisms of the foreshock and mainshock. Also shown are end points A-A' and B-B' (b) The carthquake hypocenters within $4 \mathrm{~km}$ to the northeast of the line $A-A^{\prime}$ projected onto the line. Dashed lines are projected at $65^{\circ}$ and $70^{\circ}$ from the surface traces of the Cucamonga and San Jose faults, respectively. (c) The earthquake hypocenters within $4 \mathrm{~km}$ to the southwest of the line $\mathrm{A}-\mathrm{A}^{\prime}$ projected onto the line. Dashed lines as in Figure $6 b$. (d) The earthquake hypocenters within $4 \mathrm{~km}$ of the line B-B' projected onto the line, along strike of the San Jose fault. Three zones are outlined: the aftershock zone of 1988 (A), the aftershock zone of 1990 (A and $B$ ), and the aseismic zone (C). 
(a)

Upland 28 February 1990 M5.2

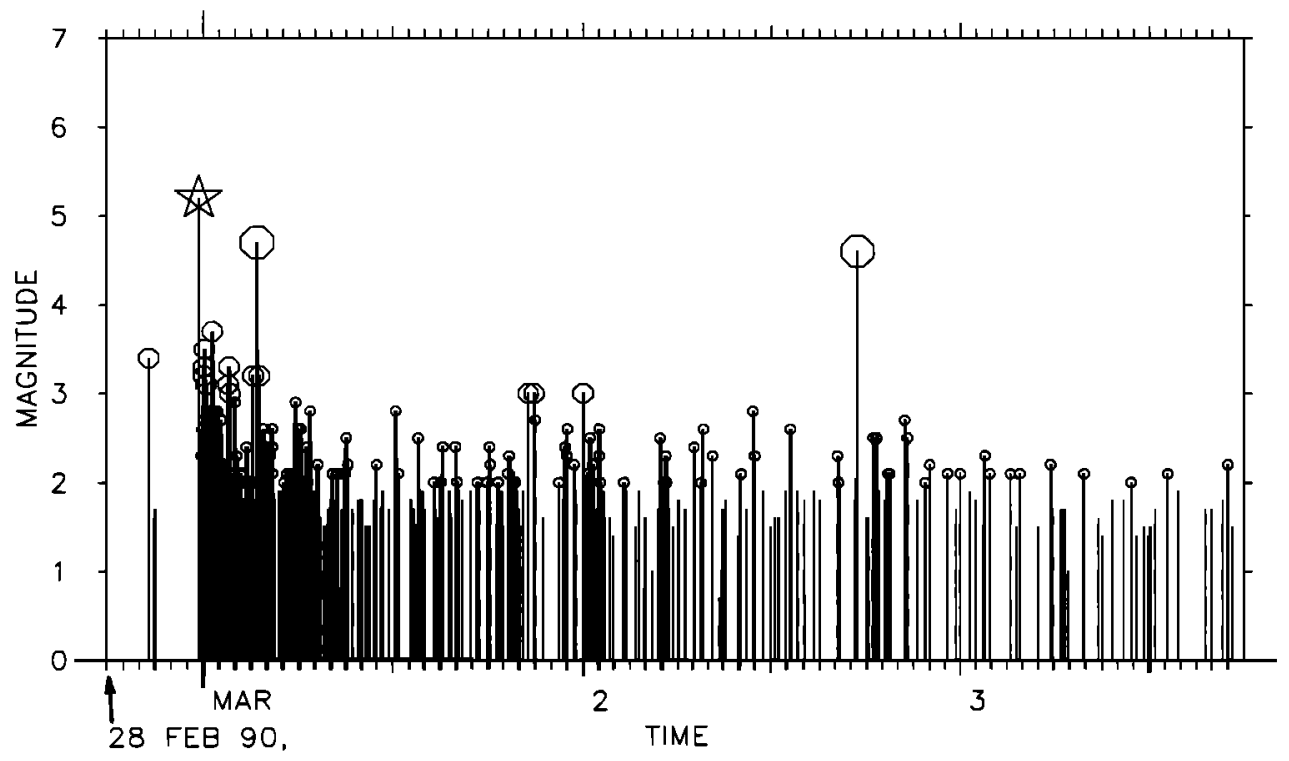

(b)
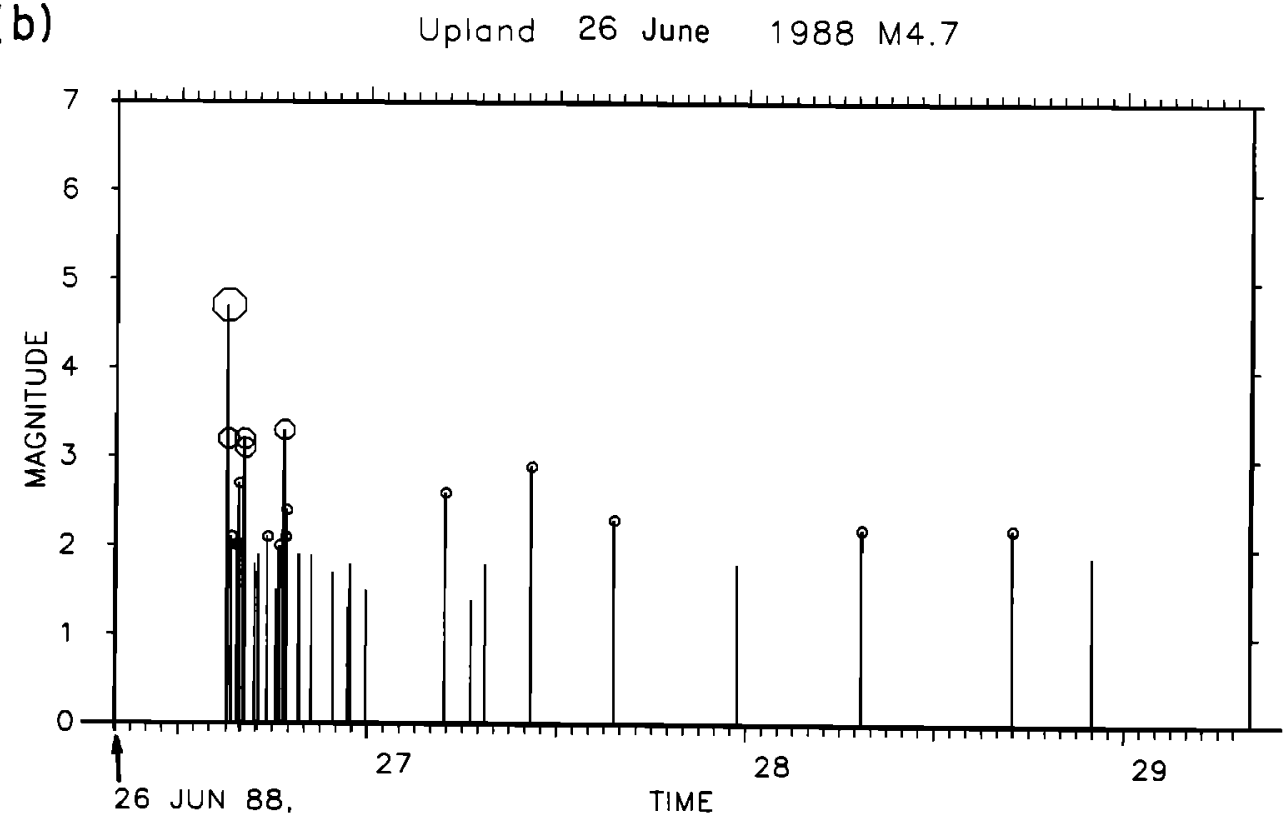

Fig. 7. (a) The magnitudes of the foreshocks, mainshock (labeled with a star), and aftershocks of the first 3 days of the 1990 sequence plotted against time. $(b)$ The magnitudes of the mainshock and aftershocks of the first 3 days of the 1988 sequence plotted against time.

be caused by stress heterogeneity around the mainshock rupture.

The aftershock zone of the 1990 earthquake, like the smaller 1988 sequence, is much deeper than it is wide. The aftershocks were confined to a zone $4 \mathrm{~km}$ long and $10 \mathrm{~km}$ deep for the first 6 weeks of the sequence. On April 16 the aftershock zone suddenly extended $3-4 \mathrm{~km}$ to the southwest along the same trend. These late aftershocks all occurred between 3 and $5 \mathrm{~km}$ depth on a segment of the San Jose fault, which probably did not rupture in the mainshock [Dreger and Helmberger, 1991]. When viewed along strike
(Figure 6d), the southwesterm edge of the deeper aftershocks and the bottom of the late, shallow aftershocks define sharp edges to the aseismic part of the fault, labeled zone $C$. This lack of aftershocks and sharp edges in zone $C$ indicates that this may be an unbroken asperity that could rupture in a future earthquake [e.g., Malin et al., 1989].

Depth distribution. The hypocenter of the 1990 Upland earthquake, at $5.2 \mathrm{~km}$ depth, is unusual in both its shallowness and its nearness to the top of its aftershock zone. The seismic moments of earthquakes of the 1990 Upland sequence are plotted as a function of depth in Figure 


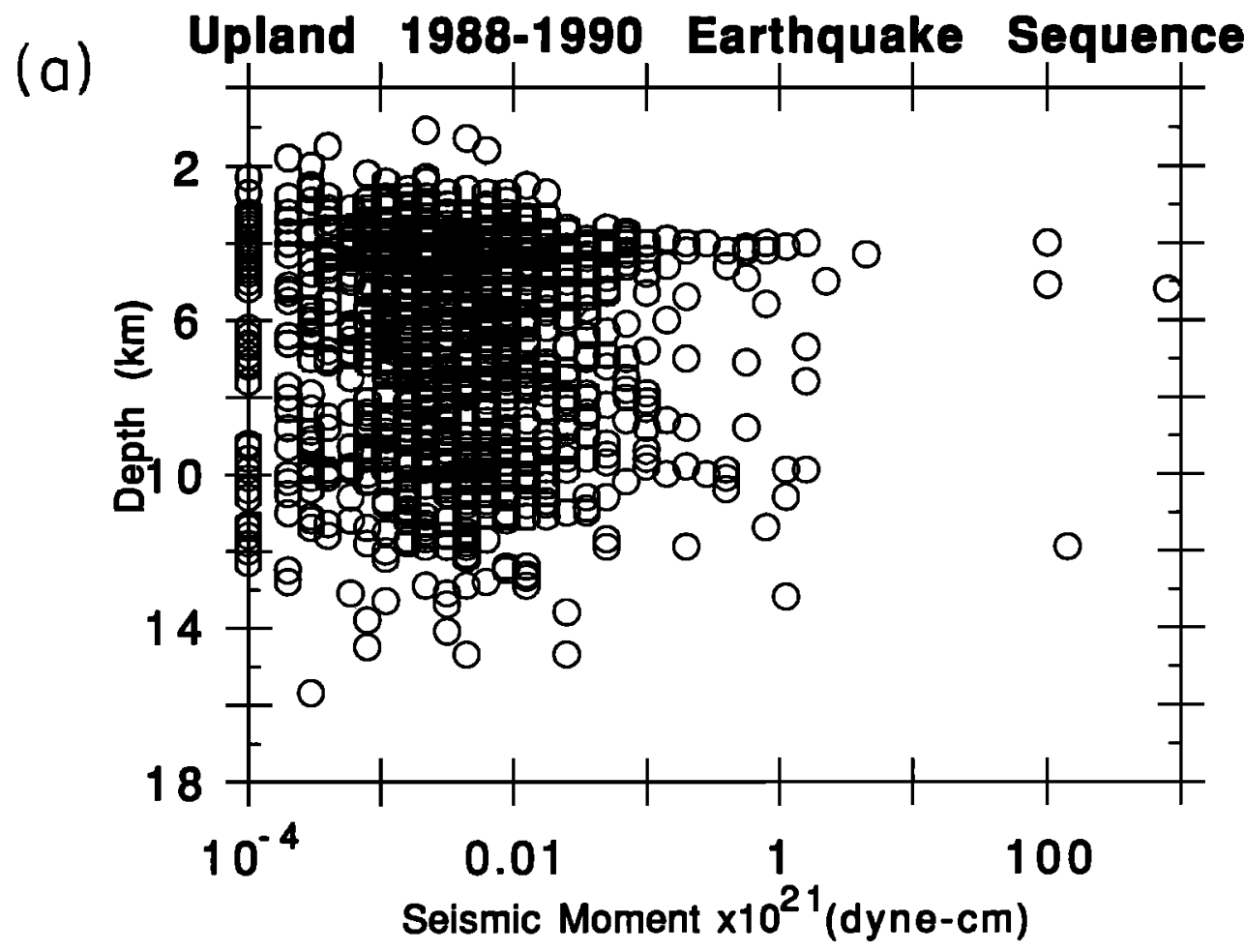

(b)

Upland 1990

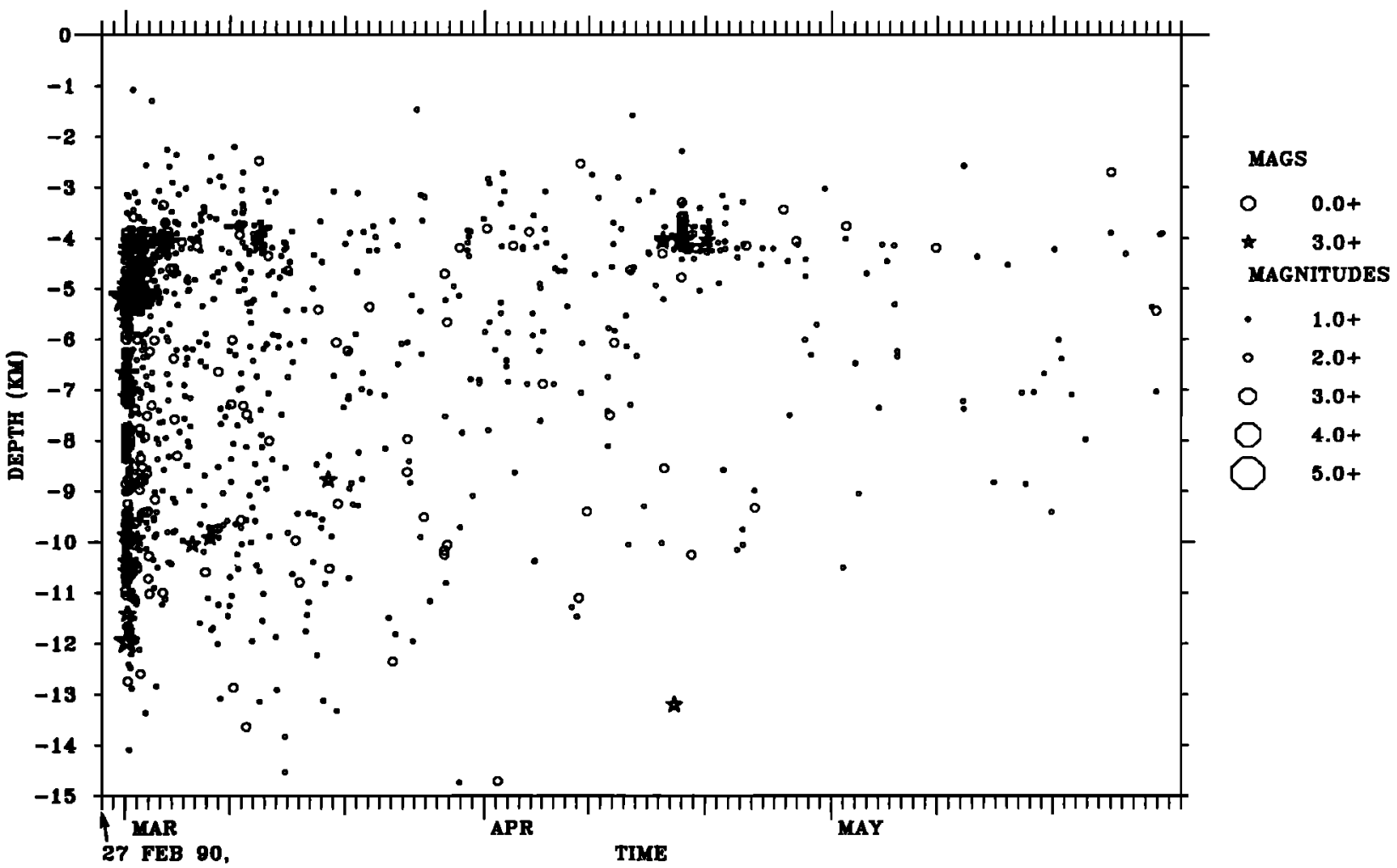

Fig. 8. (a) Seismic moment versus depth for earthquakes of the 1988 and 1990 Upland earthquake sequences. Seismic moments were calculated from local magnitudes using the moment-magnitude relation of Hanks and Kanamori [1979]. (b) The hypocentral depth plotted against time for earthquakes of the 1990 Upland earthquake sequence. Earthquakes $M_{L} \geq 4.0$ are shown by stars. 
8a The seismic moments were estimated from the magnitudes by using the moment-magnitude relation of Hanks and Kanamori [1979]. The earthquakes with the largest seismic moments are concentrated at two depths, at 4-6 $\mathrm{km}$ around the hypocenter of the 1990 mainshock and at 10-12 km. Thus, although no gap in aftershock activity can be seen when all recorded aftershocks are considered, a gap does appear for aftershocks of $M_{L} \geq 3.8$. This suggests that some moment release occurred during the mainshock over the depth range of $5-11 \mathrm{~km}$. However, the large numbers of $M_{L}=2$ to $M_{L}=3$ aftershocks in this depth range suggest that moment release was incomplete.

The depth distribution of the aftershocks following the 1990 mainshock is shown in Figure $8 b$. The original aftershock zone extended from the focus of the mainshock down to $15 \mathrm{~km}$ depth. However, the deep aftershocks tapered off within 2 weeks. Three months after the mainshock the depth range has narrowed from $3-15 \mathrm{~km}$ to 3-7 km depth. This suggests that the deeper part of the aftershock zone has within a short time regained a stress state similar to the state that existed before the mainshock.

Overview of the 1988 and 1990 sequences. Both the 1988 and the 1990 aftershock sequences are shown in map view and cross section in Figure 9. The 1990 zone was larger than the 1988 zone by a factor of 2 . Both zones are very tightly confined on the southwest edge and show the unusual property of being much deeper than they are wide. The focal mechanism of the 1988 mainshock and the hypocentral distribution of all the aftershocks suggest that the average dip of the San Jose fault is $70^{\circ}$. In detail the dip of the San Jose fault, however, varies with depth. The fault appears to dip $70^{\circ}$ above $5-6 \mathrm{~km}$, be almost vertical between 6 and $9-10 \mathrm{~km}$, dip at less than $60^{\circ}$ between 9-10 and about $12 \mathrm{~km}$, and then return to $70^{\circ}$ below $13 \mathrm{~km}$. Many of the aftershocks to both mainshocks are concentrated at the bends at about 5 and $9 \mathrm{~km}$. The focus of the 1988 mainshock is near the lower bend, while the focus of the 1990 mainshock is near the upper bend. This variation in dip is not thought to be an artifact of the velocity model used because the bends do not coincide with the layer boundaries. The dip of the San Jose fault south of the 1988 and 1990 sequences cannot be resolved because of sparsity of activity but could be as steep as $85^{\circ}$ (Figure 9c).

The 1990 earthquake may have broken an adjacent segment of the same fault or reactivated and extended the aftershock zone of the 1988 earthquake (Figure 9d). The reactivation of the fault area that had aftershocks in 1988 suggests that the 1988 and 1990 mainshocks may be causally related. Both sequences show rupture along the northeast striking section of the San Jose fault. Farther to the west where the strike is more east-northeasterly, there is almost total absence of seismicity along the fault, except for a few shallow events and a few deep events. The lack of small earthquakes along the seismogenic part of the fault (zone $C$ in Figure 9d) suggests that this part may be locked and could be viewed as an unbroken asperity.

\section{Focal Mechanisms}

Events of $M_{L} \geq 3.0$. The focal mechanisms of $M_{L} \geq 3.0$ events that occurred in the 1988 and 1990 sequences are shown in map and cross section in Figure 10. The 1988 events are between 9.5 and $7 \mathrm{~km}$, while the 1990 events lie between 12 and $4 \mathrm{~km}$ depth. Both mainshocks resulted from left-lateral strike slip on northeast trending planes. Most of the large aftershocks, located both near and away from the fault surface, have similar focal mechanisms with small variations in the strike or dip of the nodal planes. The dips and hypocentral locations of most of the mechanisms are consistent with the sequence being on the San Jose fault.

The hypocentral locations in Figure 6 suggest that the dip of the fault plane changes with depth, from $70^{\circ}$ at the top, steepening to almost vertical between 6 and $9 \mathrm{~km}$, shallowing to $60^{\circ}$ or less between 9 and $12 \mathrm{~km}$, and then returning to $70^{\circ}$ below $12 \mathrm{~km}$. These possible changes in dip are supported by the dips of individual aftershocks at different depths (Figure 10b). The shallow and the deepest earthquakes have dips very close to $70^{\circ}$, and the events between 6 and $9 \mathrm{~km}$ are close to vertical or, like the foreshock, dip steeply to the southeast instead of northwest, while the 1988 mainshock at $9 \mathrm{~km}$ has a shallower dip, $40^{\circ}-50^{\circ}$.

Events of $M_{L} \geq 2.1$. To show the details of the faulting caused by the 1990 sequence, focal mechanisms for the foreshock, mainshock, and most of the aftershocks of $M_{L} \geq 2.1$ have been grouped into strike-slip, oblique-thrust, and oblique-normal mechanisms, which are shown separately in Figures $11 a, 11 b, 11 c$, and $11 d$. The normal mechanisms have rakes from $-25^{\circ}$ to $-155^{\circ}$, and the thrust mechanisms have rakes from $25^{\circ}$ to $155^{\circ}$. In each figure, the focal mechanisms are shown for two depth ranges, 0-6 $\mathrm{km}$ and $6-20 \mathrm{~km}$. Because most of the thrust and normal mechanisms have a significant left-lateral component, these are considered to be caused by geometrical complexities in the fault or by stress heterogeneities immediately adjacent to the fault.

The strike-slip focal mechanisms (Figures $11 a$ and $11 b$ ) dominate the data set with 77 of the 124 mechanisms. Most of these events are consistent with left-lateral strike slip on the San Jose fault. The late aftershocks to the southwest have focal mechanisms similar to the events on the central part of the fault. Several small aftershocks in the southwestern part of the main rupture between 5 and 10 $\mathrm{km}$, however, are rotated $30^{\circ}-50^{\circ}$ counterclockwise from the mainshock mechanism.

The off-fault aftershocks in the cluster to the southeast are all shallow and have nodal planes that are rotated $30^{\circ}$. $45^{\circ}$ clockwise from that of the mainshock. In conjunction with the north striking epicentral distribution of these events the focal mechanisms suggest right-lateral strikeslip faulting on a $\mathrm{N}^{\circ} \mathrm{W}$ striking fault for this cluster.

The 28 mostly oblique-thrust mechanisms (Figures $11 c$ and $11 d$ ) are distributed through the whole depth range of the aftershock zone. Most of these mechanisms show oblique thrusting with a left-lateral component on north dipping nodal planes that strike close to east-west. Given the proximity of this activity to the main frontal fault of the Transverse Ranges, these events could be attributed to an east striking thrust fault, but the hypocentral distribution of the thrust events does not support this interpretation. Instead, the thrust-faulting mechanisms are distributed around the edges of the main fault plane. Comparing the distribution of strike-slip and thrust mechanisms in the two depth ranges (Figures $11 a, 11 b$, 
Upland 1981-1990
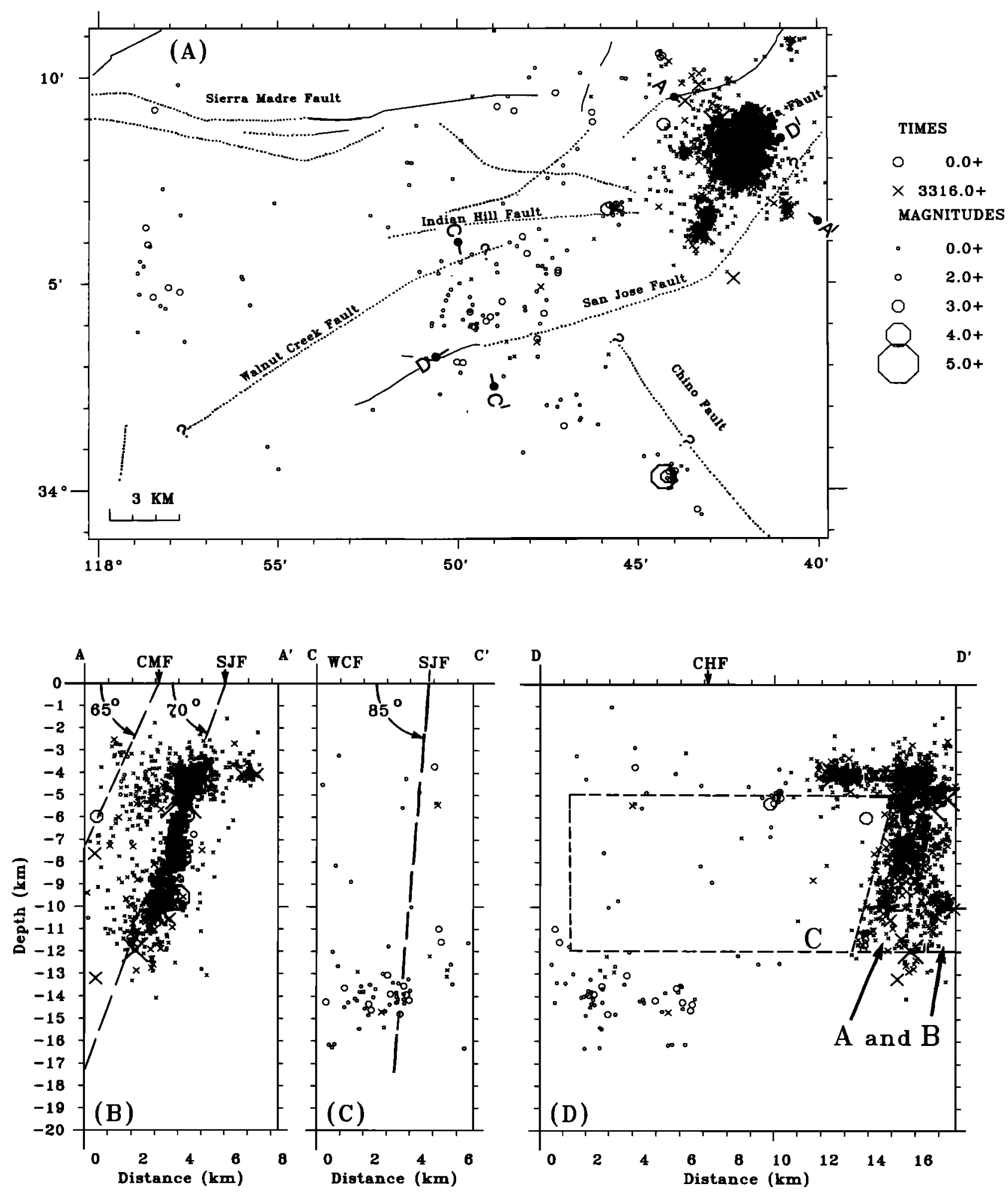

Fig. 9. Earthquakes recorded by the Southern California Seismic Network between 1981 and 1989 (shown by circles) and 1990 (shown by crosses). (a) A map showing earthquake epicenters and active faults and end points A-A', C-C', and D-D' as in Figure 5. (b) The earthquake hypocenters within $4 \mathrm{~km}$ of the line $A-A^{\prime}$ projected onto the line. Dashed lines are projected at $65^{\circ}$ and $70^{\circ}$ from the surface traces of the Cucamonga and San Jose faults, respectively. (c) The earthquake hypocenters within $5 \mathrm{~km}$ of the line C-C' projected onto the line. Dashed line is projected at $85^{\circ}$ from the surface trace of the San Jose fault. (d) The earthquake hypocenters within $6 \mathrm{~km}$ of the line D-D' projected onto the line, along strike of the San Jose fault. Three zones are outlined: the aftershock zone of 1988 (A), the aftershock zone of 1990 (A and B), and the aseismic zone (C). 

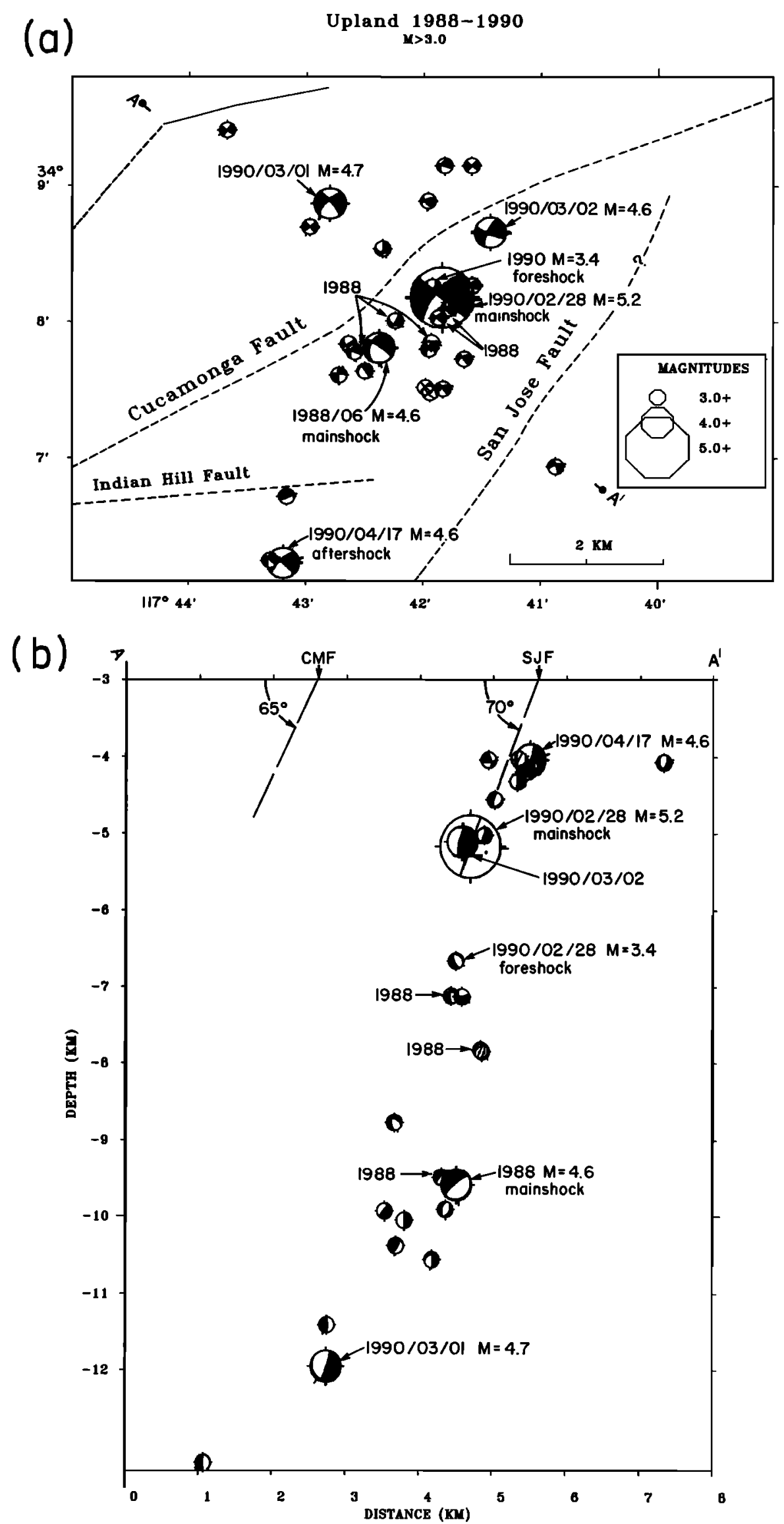

Fig. 10. Single-event, focal mechanisms of $M_{L} \geq 3.0$ earthquakes of the 1988 and 1990 Upland earthquake sequences. (a) A map of lower hemisphere, focal mechanisms, and active faults from Jennings [1975]. End points A-A' are also shown. (b) A depth cross section of the focal mechanisms projected onto the line A-A'. 
Upland Sequence Focal Mechanisms 1990

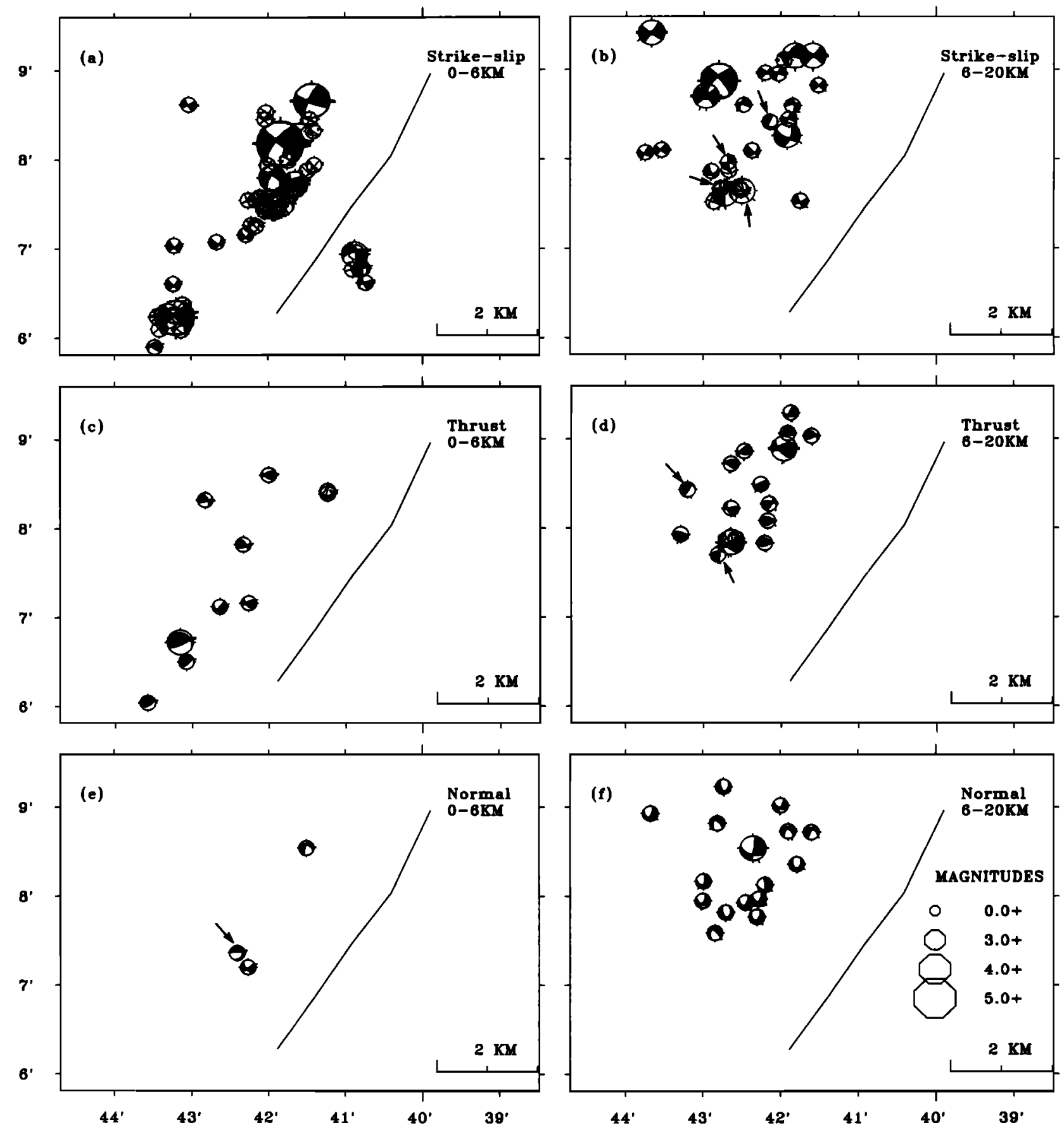

Fig. 11. Maps of the focal mechanisms of earthquakes $\left(M_{L} \geq 2.1\right)$ of the 1990 Upland earthquake sequence. Anomalous focal mechanisms are labeled with an arrow. ( $a$ and $b$ ) Maps of the strike-slip mechanisms with hypocenters between $0-6 \mathrm{~km}$ and $6-20 \mathrm{~km}$ depth. These mechanisms have rakes on the preferred planes within $25^{\circ}$ of pure strike slip $\left(-25^{\circ}\right.$ to $25^{\circ}, 155^{\circ}$ to $\left.205^{\circ}\right)$. Where significant overlap of focal mechanisms occurs, the compressional quadrants are not shaded, but one is labeled with a T. ( $c$ and $d$ ) Maps of the oblique-thrust mechanisms with hypocenters between $0-6 \mathrm{~km}$ and $6-20 \mathrm{~km}$ depth. These mechanisms have rakes on the preferred planes within $65^{\circ}$ of pure normal $\left(-155^{\circ}\right.$ to $\left.-25^{\circ}\right)$. ( $e$ and $f$ ) Maps of the oblique-normal mechanisms with hypocenters between $0-6 \mathrm{~km}$ and $6-20 \mathrm{~km}$ depth. These mechanisms have rakes on the preferred planes within $65^{\circ}$ of pure reverse $\left(25^{\circ}\right.$ to $\left.155^{\circ}\right)$.

$11 c$, and 11d) shows a central core of strike-slip mechanisms on the main fault plane and a ring of thrust mechanisms around them. Thus the thrust mechanisms appear to be local adjustments to stress concentrations rather than a dominant tectonic feature.

Most of the 19 oblique-normal mechanisms (Figures $11 e$ and $11 f$ ) occurred near the hypocenter of the mainshock, perhaps indicating a greater release of the uniform component of the tectonic stress field around the mainshock. The normal faulting events are concentrated on the southeast side of the mainshock plane.

The distribution of focal mechanisms can also be seen in 
Figure 12 where the dip direction ( $\alpha$, the azimuth plus $90^{\circ}$ ) is plotted against the rake $(\lambda)$ for the planes thought to be the actual fault plane. The strike-slip mechanisms dominate with the largest group similar to the mainshock $\left(\alpha \approx 310^{\circ}, \lambda=0^{\circ}\right)$. A significant number of aftershocks have mechanisms similar to the foreshock, dipping to the southeast instead of northwest $\left(\alpha \approx 120^{\circ}, \lambda \approx 0^{\circ}\right)$. The offfault cluster can be seen with right-lateral strike-slip motion on north striking planes $\left(\alpha \approx 255^{\circ}, \lambda \approx 180^{\circ}\right)$. The normal mechanisms closely parallel the left-lateral strikeslip planes similar to the foreshock $\left(\alpha \approx 120^{\circ}, \lambda \approx-45^{\circ}\right)$. The thrust events $\left(\lambda \approx 40^{\circ}-130^{\circ}\right)$ generally dip to the north.

In summary, the focal mechanisms show that the faulting was left-lateral strike-slip motion along the San Jose fault. Some of the focal mechanisms of the aftershocks show faulting complexities that result from stress heterogeneities adjacent to the mainshock rupture. The heterogeneity is not as great as was reported in the vicinity of the Loma Prieta earthquake by Michael et al. [1990].

\section{State of Stress}

To invert for the state of stress, one nodal plane from each of the 117 focal mechanisms was chosen as the most likely actual fault plane. For most of the strike-slip mechanisms the northeast striking, left-lateral, strike-slip nodal planes were chosen except for the off-fault cluster for which the north striking, right-lateral planes were chosen. The normal faults with a left-lateral component and the thrust nodal planes that dip to the north were used (Table 1). The data included 117 nodal planes that are plotted in Figures 12 and $13 a$. The results of the stress inversion are plotted on a stereonet in Figure 13 and listed in Table 2. The maximum horizontal stress is north-south, and $\phi=0.45$, indicating that all three principal stresses differ in value. The three principal stress axes with the $95 \%$ confidence limits show that the state of stress is consistent with strike-slip faulting. The $95 \%$ confidence limits were

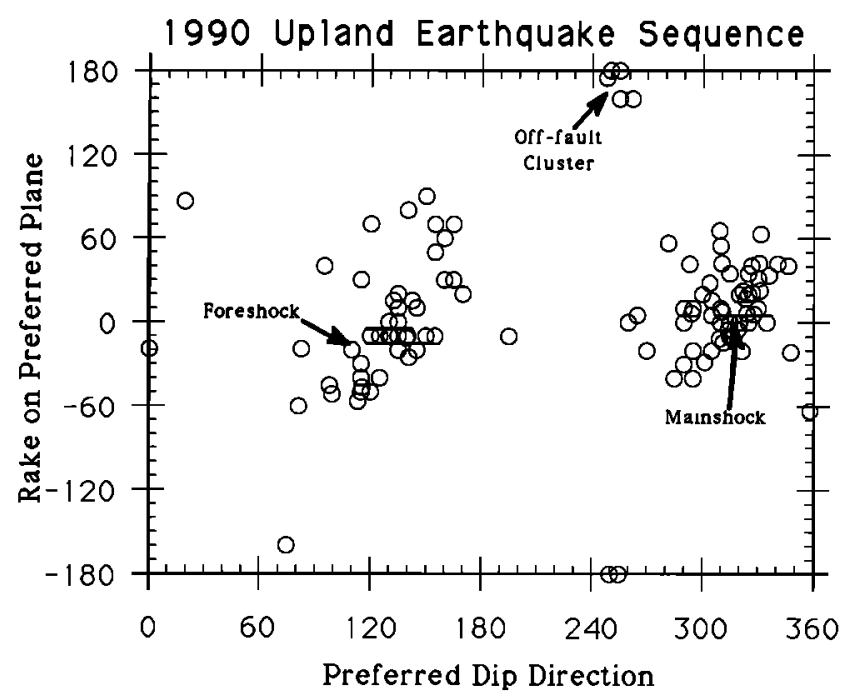

Fig. 12. The dip direction ( $90^{\circ}$ clockwise from the strike) of the plane thought to be the actual fault plane plotted against the rake on that plane for the focal mechanisms of the 1990 Upland sequence. calculated assuming $30 \%$ of the planes were picked incorrectly.

This north-south maximum principal stress (azimuth $=$ $0^{\circ}$ ) and vertical intermediate principal stress are essentially the same as that determined for the northeastern Los Angeles basin by Hauksson [1990]. Using focal mechanisms of the 1977-1989 background seismicity, Hauksson found a maximum compressive stress azimuth of $0^{\circ}$ for this region. The $\phi$ value has also not changed significantly, from $\phi=0.49$ for the background to $\phi=0.45$ for the aftershocks. The stress state for the aftershocks was also calculated for different time periods within the aftershock sequence, but no variation in stress with time

\section{UPLAND AFTERSHOCKS : STRESS STATE}

\section{$30 \%$ OF FAULT PLANES ASSUMED PICKED INCORRECTLY}

(a)

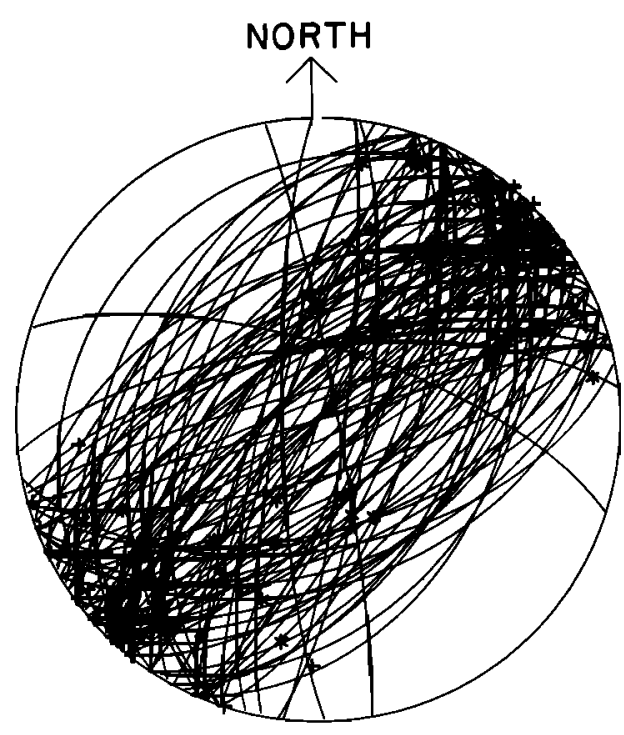

(b)

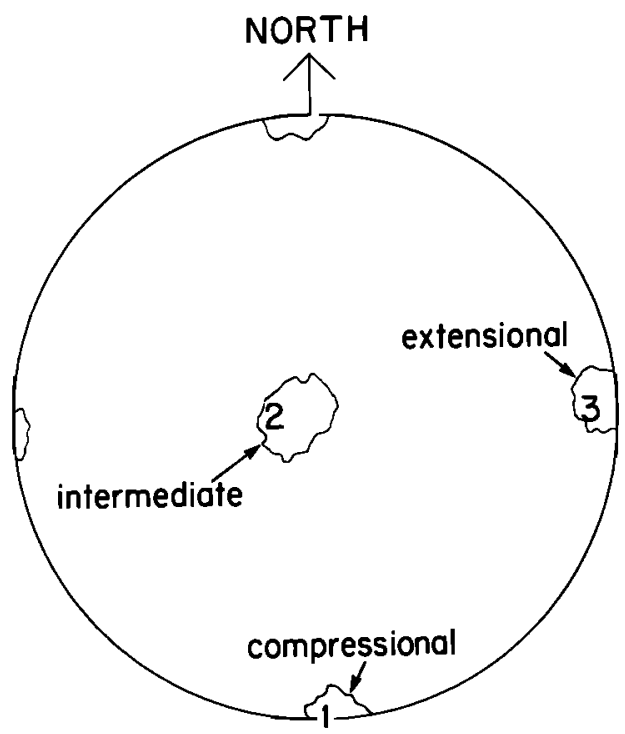

Fig. 13. Stereonet projections of (a) the preferred fault planes from focal mechanisms of the 1990 Upland aftershocks with the slip direction shown by a cross and $(b)$ the results of the stress inversion showing the $95 \%$ confidence limits of the directions of the three principal stresses. 
TABLE2. Stress Inversion Results for the 1990 Upland Earthquake Sequence

\begin{tabular}{|c|c|c|c|c|c|c|c|c|c|}
\hline \multirow{2}{*}{$\begin{array}{l}\text { Number } \\
\text { of } \\
\text { Planes }\end{array}$} & \multirow[b]{2}{*}{$\varnothing$} & \multicolumn{2}{|c|}{$\begin{array}{c}\text { Maximum } \\
\text { Principal } \\
\text { Stress } \\
\end{array}$} & \multicolumn{2}{|c|}{$\begin{array}{c}\text { Intermediate } \\
\text { Principal } \\
\text { Stress }\end{array}$} & \multicolumn{2}{|c|}{$\begin{array}{c}\text { Minimum } \\
\text { Principal } \\
\text { Stress } \\
\end{array}$} & \multicolumn{2}{|c|}{$\begin{array}{c}\text { Average } \\
\text { Misfit Angle } \\
\text { B }\end{array}$} \\
\hline & & Trend & Plunge & Trend & Plunge & Trend & Plunge & Mean & s. d. \\
\hline 117 & 0.45 & $-180^{\circ}$ & $0.2^{\circ}$ & $-89^{\circ}$ & $77^{\circ}$ & $90^{\circ}$ & $13^{\circ}$ & $20^{\circ}$ & $19^{\circ}$ \\
\hline
\end{tabular}

was seen. Other aftershock sequences have demonstrated significant differences in the state of stress compared to the background seismicity (Loma Prieta [Michael et al., 1990] and North Palm Springs [Michael and Jones, 1986]) or with time within the sequence (Coalinga [Michael, 1987b] and Oceanside [Hauksson and Jones, 1988]). The lack of change in the state of stress compared to the background or within the sequence suggests that the stress along the San Jose fault has not been relieved except possibly in the immediate vicinity of the rupture surface of the 1990 mainshock.

The stress inversion identified seven anomalous focal mechanisms that show very poor fit to the stress inversion and were removed from the inversion; they are marked with arrows in Figure 11. Three of the strike-slip events show right-lateral motion on northeast striking nodal planes, which is opposite to the motion observed in the mainshock. The other events, one strike-slip, one normal, and two thrust-faulting events, have one nodal plane that is subhorizontal. These events apparently are not directly caused by the tectonic stress field that caused the mainshock. They could be caused by an inhomogeneous stress field or by fluid flow adjacent to the rupture surface of the mainshock.

\section{Earthquake Statistics}

The rate of occurrence of aftershocks in time and magnitude space can be described by

$$
\lambda(t, \mathrm{M})=10^{\left(a+b\left(\mathrm{M}_{m}-\mathrm{M}\right)\right)}(t+c)^{-p}
$$

where $M_{m}$ is the magnitude of the mainshock, $M$ is magnitude, $t$ is time, and $a, b, c$, and $p$ are constants [Reasenberg and Jones, 1989]; $b$ is the usual $b$ value from the Gutenberg-Richter relation, $p$ is the decay rate from Omori's law, and $a$ represents the overall productivity of the sequence. The constants have been determined for a suite of California aftershock sequences and shown to be normally distributed around means of $a=-1.76, b=0.90$, and $p=1.05$. The variations between sequences are real and may be related to tectonic regime, heat flow, and state of stress [e.g., C. Kisslinger and L. M. Jones, Properties of aftershock sequences in southern Califomia, submitted to Journal of Geophysical Research, 1991].

These constants have been determined for both the 1988 and the 1990 Upland aftershock sequences (Table 3). Within the error bars the four constants are the same for the two sequences. Although many sequences can have, for instance, the same $p$ or $b$ value, it is unusual to have two sequences where all four constants have the same value [Reasenberg and Jones, 1989].

\section{Discussion}

\section{Regional Tectonics}

Both Upland earthquakes resulted from left-lateral strikeslip faulting on the northeast striking San Jose fault near where it splays off from the frontal fault of the Transverse Ranges. The December $1988 M_{L}=4.9$ Pasadena earthquake showed similar faulting with left-lateral slip on the eastnortheast striking Raymond fault, which also splays from the frontal fault system. These three earthquakes are the first moderate earthquakes $\left(M_{L}>4.5\right)$ to occur on these leftlateral faults in more than 60 years of local instrumental recording in southem California.

Several active, southwest striking, left-lateral faults splay south from the front of the Transverse Ranges and thus must be playing an active role in the tectonics of the Ranges and the Los Angeles basin (Figure 14). The Raymond, San Jose, Red Hill, and Indian Hill faults and the Fontana seismicity trend all appear to be active leftlateral faults. In addition, the Hollywood and Santa Monica faults are usually considered to be oblique-reverse and left-lateral features [e.g., Ziony and Yerkes, 1985], as was the Raymond fault before the 1988 earthquake. With so many active faults the left-lateral faulting must be considered an important component of the deformation associated with the collision of the Transverse Ranges and the Peninsular Ranges blocks.

Transfer of slip. Slip on the San Jose fault and other left-lateral faults may be closely related to deformation of the range front. Crook et al. [1987] and Morton and Matti

TABLE 3. Aftershock Statistics for Upland Earthquakes

\begin{tabular}{lcccc}
\hline & \multicolumn{5}{c}{ Values } \\
\cline { 2 - 5 } Earthquake & $a$ & $b$ & $p$ & $c$ \\
\hline 1990 & $-1.98 \pm 0.18$ & $1.14 \pm 0.05$ & $1.04 \pm 0.03$ & $0.04 \pm 0.02$ \\
1988 & $-2.09 \pm 0.34$ & $1.01 \pm 0.11$ & $0.96 \pm 0.08$ & $0.01 \pm 0.03$ \\
\hline
\end{tabular}


(a)

\section{THRUST FAULTING MODEL}

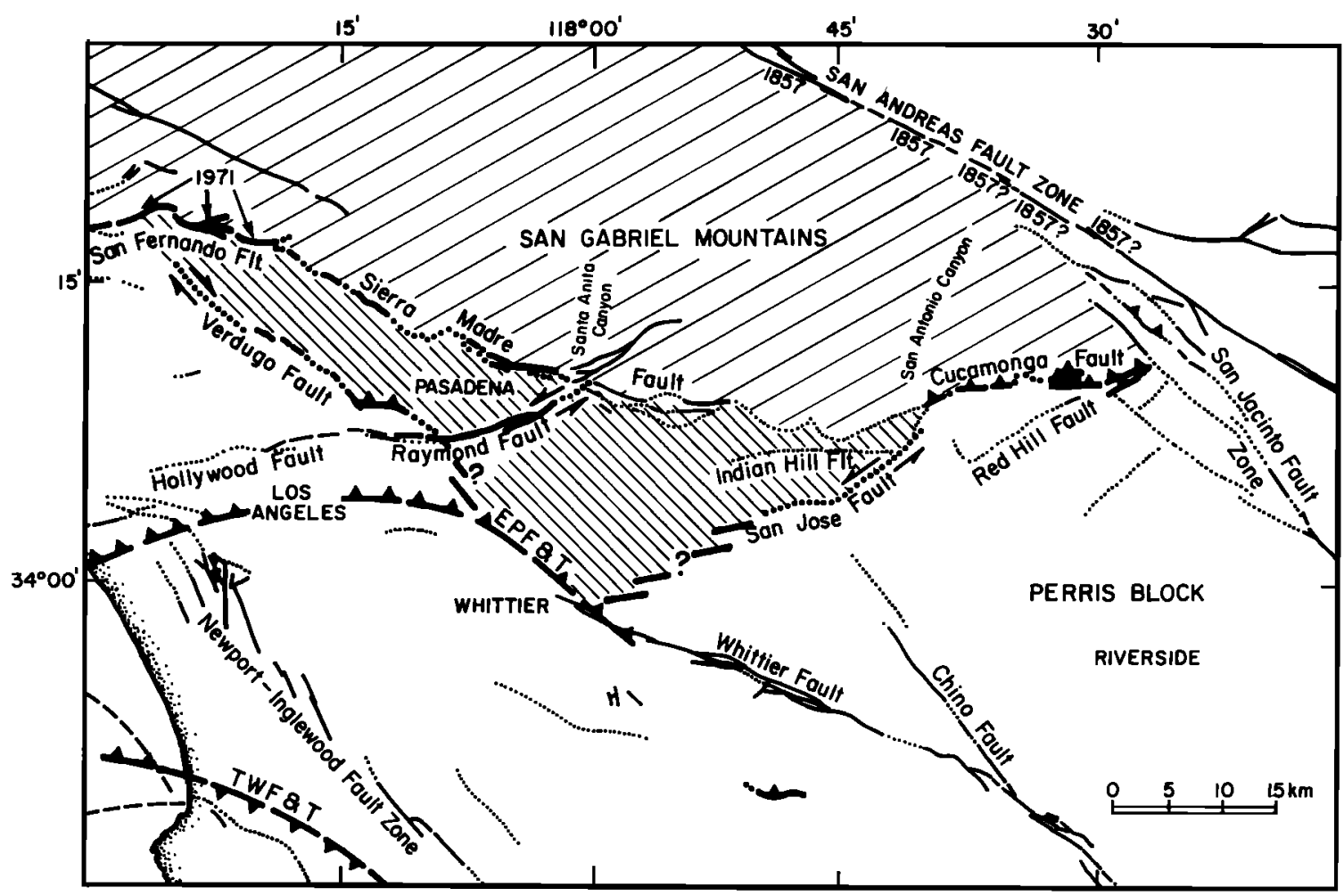

(b)

\section{STRIKE-SLIP FAULTING MODEL}

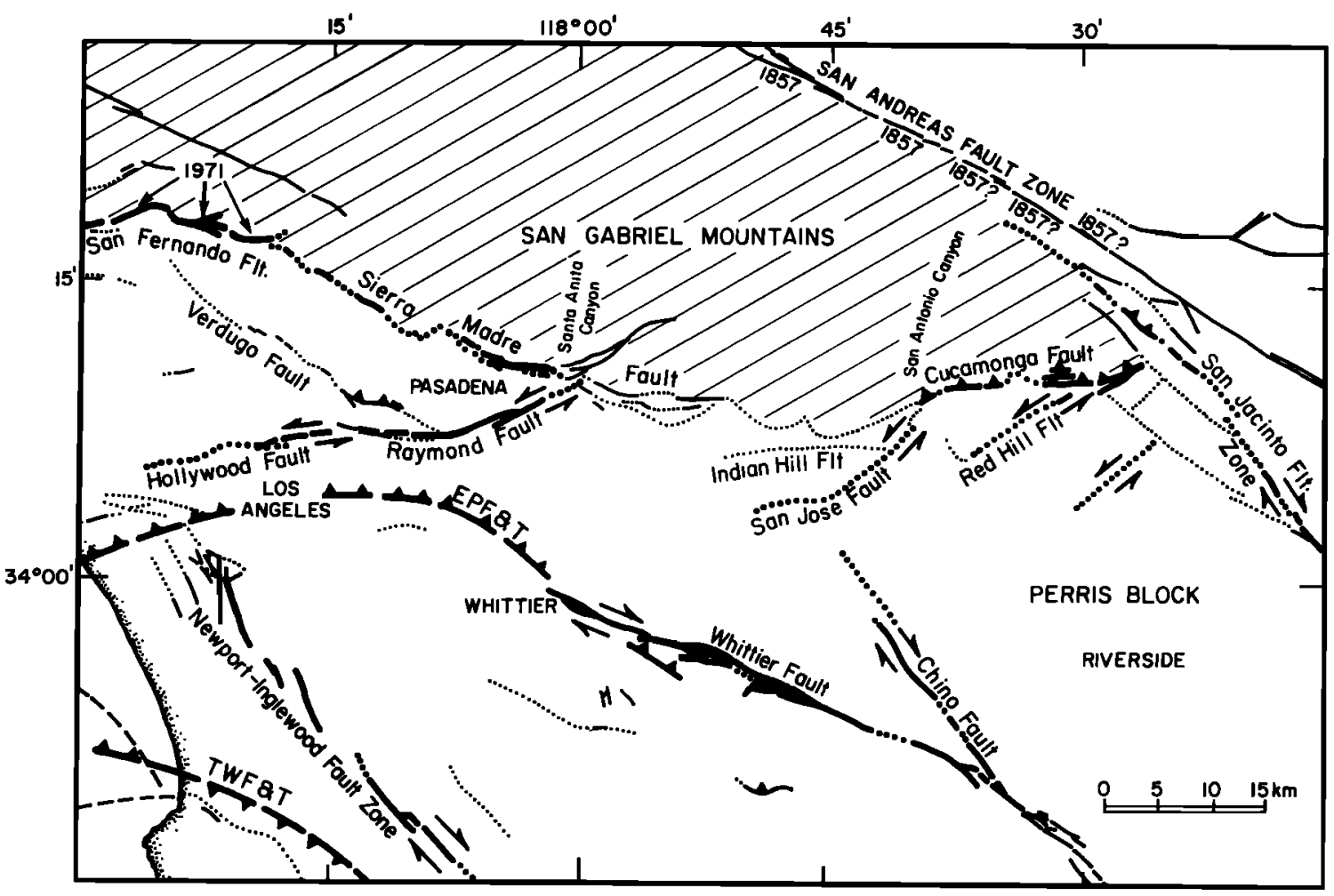

Fig. 14. Maps of the region of the Upland earthquakes showing active faults from Ziony and Jones [1989]. Faults are dotted where inferred, dashed where concealed, and solid where well located. (a) The thrust faulting model where the shading illustrates where the compressional tectonics of the Transverse Ranges may extend to the south of the Sierra Madre fault. In this model the San Jose fault transfers some of the thrust motion to the Elysian Park thrust, located to the south of the Sierra Madre fault. Some of the slip may be transferred back to the northwest along the Verdugo fault. (b) The strike-slip faulting model where the northeast trending strikeslip faults are secondary faults related to the abrupt termination of the northwest trending strike-slip faults. 
[1987] determined the slip rate along the Sierra Madre and Cucamonga faults. They showed that the segment of the Sierra Madre fault extending from Santa Anita Canyon, where the Raymond fault intersects the front, to San Antonio Canyon, the intersection of the San Jose fault with the Cucamonga fault (Figure 14a), has a significantly lower slip rate than the fault segments of the range front to the west and to the east. Moreover, this segment of the range front has no evidence of late Quaternary motion [Crook et al., 1987; Ziony and Jones, 1989]. These observations and the coincident activation of the San Jose and Raymond faults suggest that some of the convergence along this segment of the range front could be accommodated by thrust faults located south of the exposed reverse faults. As shown schematically in Figure $14 a$, this could be associated with blind thrusts such as the Elysian Park fault, which caused the $1987\left(M_{L}=5.9\right)$ Whittier Narrows earthquake [Hauksson and Jones, 1989], or the Whittier fault, which has a large reverse component [e.g., Lamar, 1991; Ziony and Yerkes, 1985]. However, because the slip rate on the frontal fault is higher west of Santa Anita Canyon, any such transfer of motion to the south must include a return of some of the slip to the range front to the west, possibly along the Verdugo-Eagle Rock fault. The low slip rates, lack of surficial exposure, and lack of significant background seismicity, however, make it difficult to quantify this model.

Secondary faulting. The left-lateral faults could instead represent secondary faulting related to the termination of the northwest striking, right-lateral, strike-slip faults to the south. This is illustrated by the strike-slip faulting model in Figure 14b. Because the left-lateral faults apparently have much lower slip rates than either the reverse faults or the right-lateral faults, these are considered to be secondary faulting. The primary motion of the Peninsular Ranges is northwestward on right-lateral, strike-slip faults, the San Jacinto fault to the east and the Elsinore-Whittier fault and Newport-Inglewood fault to the west. These right-lateral and secondary left-lateral faults and seismicity trends can be paired together such that the Fontana trend is associated with the San Jacinto fault, the San Jose fault with the Chino fault, the Raymond fault with the Whittier fault, and the Santa Monica fault with the Newport-Inglewood fault. Continued slip on both the right-lateral and the left-lateral faults moves crustal material westward around the big bend of the San Andreas fault, as was suggested by Weldon and Humphreys [1986]. This movement is similar, though on a much smaller scale, to the movement of China eastward away from the collision of India and Asia [Tapponnier and Molnar, 1977].

The existence of the left-lateral faults in the Peninsular Ranges block also suggests that the Transverse Ranges block is locally stronger than the Peninsular Ranges. This may be a localized decrease in strength associated with the collision and possible subduction of the upper mantle beneath the Transverse Ranges [Humphreys et al., 1984].

\section{Earthquake Potential}

Several unusual features of the Upland earthquakes can be inferred from the patterns of aftershocks. In general, fault areas where most of the moment release in the mainshock took place are noticeably deficient in aftershocks [e.g.,
Mendoza and Hartzell, 1988]. For instance, aftershocks following the 1989 Loma Prieta earthquake mostly clustered near the edges of the rupture area of the mainshock [Dietz and Ellsworth, 1990]. This is usually interpreted as showing that the stored stress on these fault areas was relieved in the mainshock so that almost none remains to cause aftershocks. The areas in which aftershocks are generated are interpreted as areas that slipped incompletely in the mainshock. No obvious holes in the 1990 aftershock activity are observed in cross section B-B' (Figure 6d). This suggests either that the areas of major moment release are so small as to be indistinguishable within the few hundred meter errors in locations of the aftershocks or that the driving stress was not completely relieved on any part of the mainshock rupture plane.

The 1988 and 1990 earthquakes occurred on adjacent or possibly overlapping segments of the San Jose fault. The 1990 mainshock occurred at the top of the aftershock zone at $5 \mathrm{~km}$ and appears to have ruptured down to about $10 \mathrm{~km}$ (because of the greater moment release at that depth, Figure 8), whereas the aftershocks occurred even deeper, to $13 \mathrm{~km}$. Most of the slip in both mainshocks appears to be between two bends in the dip of the fault at 5 and $10 \mathrm{~km}$ with the larger aftershocks concentrated at the top and bottom of this zone. The smaller aftershocks occur throughout the zone, without a gap around the mainshock hypocenters as is often observed in other Californian aftershock sequences. Many other aftershock zones expand with time, but the 1990 zone began between 4 and $15 \mathrm{~km}$ but within 2 months was limited to between 3 and $7 \mathrm{~km}$ depth, suggesting that the stress state at depth quickly returned to the same state as existed before the mainshock. The stress reflected in the focal mechanisms of the aftershocks is identical to that determined from background activity and did not change with time during the aftershock sequence. All of these factors suggest that the release of slip may have been incomplete and any stress release during the two earthquakes has not significantly altered the state of stress on the San Jose fault.

The development of seismicity patterns around the San Jose fault is similar to the development of such pattems around more active faults such as the San Andreas fault. Malin et al. [1989] reported a halo of seismicity surrounding the aseismic strong patch of the San Andreas fault, often referred to as the Parkfield asperity. They suggested that this asperity would break in the next $M_{L} \geq 6.0$ Parkfield earthquake. Similarly, Oppenheimer et al. [1990] analyzed seismicity patterns along the Calaveras fault and identified several aseismic strong patches, which they interpreted to be possible future sites of moderate-sized earthquakes. The background seismicity along the San Jose fault to the southwest of the 1988 and 1990 earthquakes surrounds an aseismic patch that is $14 \mathrm{~km}$ long and in the depth range of 5-12 km (zone $C$ in Figure 9). This pattern could be fortuitous, or it could be an indication of an asperity along the San Jose fault. The northem $8 \mathrm{~km}$ of this segment has the same orientation as the segment of the fault that ruptured in the 1988 and 1990 earthquakes.

Dilational and compressive fault bends may affect the rupture length of earthquakes [Sibson, 1989]. In particular, dilational bends may preferentially stop rupture, because no mechanism is available for rapid transfer of stress from one 
fault strand to the next [Sibson, 1989]. The bend in the San Jose fault, located about $8 \mathrm{~km}$ south of the 1990 Upland earthquake, would not inhibit a rupture starting at the southwestern edge of the 1990 sequence, because the rupture front would pass through a compressive bend. If the 14-km-long segment or possibly the whole 18-km-long fault were to rupture in one event, such an event would have a magnitude of 6.0-6.5 and would cause significant damage in the Ontario-Upland area.

\section{Conclusions}

The 1988 and 1990 Upland earthquakes occurred on the San Jose fault. The San Jose fault and other left-lateral, strike-slip faults that splay southwest from the main frontal fault of the central Transverse Ranges may transfer slip away from the central part of the frontal fault to the south, or they could represent secondary faulting related to the termination of the northwest striking, right-lateral, strike-slip faults to the south. These left-lateral faults move fragments of crustal blocks from the Peninsular Ranges block westward around the Transverse Ranges. The conspicuous background seismicity pattem, state of stress, and presence of a 14- to 18-km-long unbroken fault all suggest that future occurrence of damaging earthquakes along the San Jose fault is very likely. None of the available evidence, however, makes it possible to estimate when such an event might occur.

Acknowledgments. Andy Michael, Jim Mori, Doug Morton, and Kerry Sieh provided helpful critical reviews. We thank Doug Morton and Kerry Sieh for stimulating discussions about the tectonics of the central Transverse Ranges. We are grateful to the seismic analysts of Caltech and the USGS for quick and competent processing of the earthquake data. One of us (E.H.) was supported by USGS grant 14-08-0001-G1761 and NSF grant ERA9014787 for this work. Division of Geological and Planetary Sciences, California Institute of Technology, contribution 4929.

\section{REFERENCES}

Bortugno, E. J., and T. E. Spittler, Geologic map of the San Bernardino Quadrangle, California, Map 3A (Geol.), scale 1:250,000, Calif. Div. of Mines and Geol., Sacramento, 1986.

California Department of Water Resources (DWR), Meeting water demands in the Chino-Riverside area: Appendix A Water supply, Bull. Calif. Dep. Water Resour. 104-3, 108 pp., 1970.

Cramer, C. H., and J. M. Harrington, Seismicity and tectonics of the Cucamonga fault and the eastern San Gabriel Mountains, San Bernardino County, in Recent Reverse Faulting in the Transverse Ranges, California, edited by D. M. Morton and R. F. Yerkes, U.S. Geol. Surv. Prof. Pap., 1339, 7-26, 1987.

Crook, R. J., C. R. Allen, B. Kamb, C. M. Payne, and R. J. Proctor, Quaternary geology and seismic hazard of the Sierra Madre and associated faults, westem San Gabriel Mountains, California, in Recent Reverse Faulting in the Transverse Ranges, California, edited by D. M. Morton and R. F. Yerkes, U.S. Geol. Surv. Prof. Pap., 1339, 27-64, 1987.

Dietz, L. D., and W. L. Ellsworth, The October 17, 1989 Loma Prieta, Califomia, earthquake and its aftershocks: Geometry of the sequence from high-resolution locations, Geophys. Res. Lett., 17, 1417-1420, 1990.
Dreger, D. S., and D. V. Helmberger, Broadband modeling of local earthquakes, Bull. Seismol. Soc. Am., 80, 1162-1179, 1990.

Dreger, D., and D. V. Helmberger, Complex faulting deduced from broadband modeling of the February, 281990 Upland earthquake $\left(M_{L}=5.2\right)$, Bull. Seismol. Soc. Am., in press, 1991.

Hadley, D., and H. Kanamori, Seismic structure of the Transverse Ranges, California, Geol. Soc. Am. Bull., 88, 1469-1478, 1977.

Hanks, T., and H. Kanamori, A moment magnitude scale, $J$. Geophys. Res., 84, 2348-2350, 1979.

Hauksson, E., Earthquakes, faulting, and stress in the Los Angeles Basin, J. Geophys. Res., 95, 15,365-15,394, 1990.

Hauksson, E., and L. M. Jones, The July 1986 Oceanside $\left(M_{L}=5.3\right)$ earthquake sequence in the Continental Borderland, southern California, Bull. Seismol. Soc. Am., 78, 1885-1906, 1988.

Hauksson, E., and L. M. Jones, The 1987 Whittier Narrows earthquake sequence in Los Angeles, southern California: Seismological and tectonic analysis, J. Geophys. Res., 94, 9569-9590, 1989.

Humphreys, E., R. W. Clayton, and B. H. Hager, A tomographic image of mantle structure beneath southern California, Geophys. Res. Lett., 11, 625-627, 1984.

Jennings, C. W., Fault map of California with volcanoes, thermal springs and thermal wells, scale 1:750.000, geol. data map 1, Calif. Div. of Mines and Geol., Sacramento, 1975.

Jones, L. M., K. E. Sieh, E. Hauksson, and L. K. Hutton, The 3 December 1988 Pasadena, California earthquake: Evidence for strike-slip motion on the Raymond fault, Bull. Seismol. Soc. Am., 80, 474-482, 1990.

Klein, F. W., User's guide to HYPOINVERSE. A program for VAX and PC350 computers to solve for earthquake locations, U.S. Geol. Surv. Open File Rep., 85-515, 24 pp., 1985.

Lamar, D. L., Right-slip on Whittier fault system, southern California, in Field Guide of Whittier Fault, edited by $\mathrm{E}$. Gath, Southern California Section, Association of Engineering Geologists, Los Angeles, in press, 1991.

Malin, P., S. N. Blakeslee, M. G. Alvarez, and A. G. Martin, Microearthquake imaging of the Parkfield asperity, Science, 244, 557-559, 1989.

Mendoza, C., and S. H. Hartzell, Aftershock patterns and mainshock faulting, Bull. Seismol. Soc. Am., 78, 14381449, 1988.

Michael, A. J., Determination of stress from slip data: Faults and folds, J. Geophys. Res., 89, 11,517-11,526, 1984.

Michael, A. J., Use of focal mechanisms to determine stress: A control study, J. Geophys. Res., 92, 357-368, 1987 .

Michael, A. J., Stress rotation during the Coalinga aftershock sequence, J. Geophys. Res., 92, 7963-7979, $1987 \mathrm{~b}$.

Michael, A. J., and L. M. Jones, Stress fluctuations due to the North Palm Springs earthquake, Eos Trans. AGU., 67, 1090, 1986.

Michael, A. J., W. L. Ellsworth, and D. H. Oppenheimer, Coseismic stress changes induced by the 1989 Loma Prieta, California earthquake, Geophys. Res. Lett., 17, 1441-1444, 1990.

Mori, J., and S. H. Hartzell, Source inversion of the 1988 Upland, California, earthquake: Determination of a fault plane for a small event, Bull. Seismol. Soc. Am., 80, 507518, 1990.

Morton, D. M., and J. C. Matti, The Cucamonga fault zone: Geologic setting and Quaternary history, in Recent Reverse Faulting in the Transverse Ranges, California, edited by D. M. Morton and R. F. Yerkes, U.S. Geol. Surv. Prof. Pap., 1339, 179-203, 1987. 
Oppenheimer, D. H., W. H. Bakun, and A. G. Lindh, Slip partitioning of the Calaveras fault, California, and prospects for future carthquakes, J. Geophys. Res., 95, 8483-8498, 1990.

Reasenberg, P. A., and L. M. Jones, Earthquake hazard after a mainshock in California, Science, 243, 1173-1176, 1989.

Reasenberg, P., and D. Oppenheimer, FPFIT, FPPLOT, and FPPAGE: Fortran computer programs for calculating and displaying carthquake fault-plane solutions, U.S. Geol. Surv. Open File Rep. \#85-739, 109 pp., 1985.

Roecker, S., and W. L. Ellsworth, VELEST Fortran program report, U.S. Geol. Surv., Menlo Park, Calif., 1978.

Sibson, R. H., Earthquake faulting as a structural process, $J$. Struct. Geol., 11, 1-14, 1989.

Tapponnier, P., and P. Molnar, Active faulting and tectonics in China, J. Geophys. Res., 82, 2905-2930, 1977.

U.S. Geological Survey, 1:100 000-scale metric topographic map of San Bernardino, Califomia, Reston, Va., 1981.

Weldon, R. J., and G. Humphreys, A kinematic model of southern California, Tectonics, 5, 33-48, 1986.

Yerkes, R. F., T. H. McCulloh, J. E. Schoellhamer, and J. G.
Vedder, Geology of the Los Angeles Basin, California - An Introduction, U.S. Government Printing Office, Washington, D. C., 1965.

Ziony, J. I., and L. M. Jones, Map showing late Quaternary faults and 1978-1984 seismicity of the Los Angeles region, California, U.S. Geol. Surv. Misc. Ser. Map, MF-1964, 1989.

Ziony, J. I., and R. F. Yerkes, Evaluating earthquake and surface faulting potential, in Evaluating Earthquake Hazards in the Los Angeles Region - An Earth-Science Perspective, U.S. Geol. Surv. Prof. Pap. 1360, 43-92, 1985.

E. Hauksson, Seismological Laboratory 252-21, Division of Geological and Planetary Sciences, California Institute of Technology, Pasadena, CA 91125.

L.M. Jones, U.S. Geological Survey, 525 S. Wilson Avenue, Pasadena, CA 91106.

(Received October 19, 1990; revised February 11, 1991; accepted February 11, 1991.) 